\title{
Human Immunodeficiency Virus Vaccine Trials
}

\author{
Robert J. O'Connell ${ }^{1,3}$, Jerome H. Kim ${ }^{1,3}$, Lawrence Corey ${ }^{2,3}$, and Nelson L. Michael ${ }^{1,3}$ \\ ${ }^{1}$ U.S. Military HIV Research Program, Walter Reed Army Institute of Research, Silver Spring, Maryland 20910 \\ ${ }^{2}$ Fred Hutchinson Cancer Research Center, Seattle, Washington 98109-1024 \\ Correspondence: nmichael@hivresearch.org
}

More than 2 million AIDS-related deaths occurred globally in 2008, and more than 33 million people are living with HIV/AIDS. Despite promising advances in prevention, an estimated 2.7 million new HIV infections occurred in that year, so that for every two patients placed on combination antiretroviral treatment, five people became infected. The pandemic poses a formidable challenge to the development, progress, and stability of global society 30 years after it was recognized. Experimental preventive HIV-1 vaccines have been administered to more than 44,000 human volunteers in more than 187 separate trials since 1987. Only five candidate vaccine strategies have been advanced to efficacy testing. The recombinant glycoprotein (rgp)120 subunit vaccines, AIDSVAX B/B and AIDSVAX B/E, and the Merck Adenovirus serotype (Ad) 5 viral-vector expressing HIV-1 Gag, Pol, and Nef failed to show a reduction in infection rate or lowering of postinfection viral set point. Most recently, a phase III trial that tested a heterologous prime-boost vaccine combination of ALVAC-HIV vCP1521 and bivalent rgp120 (AIDSVAX B/E) showed 31\% efficacy in protection from infection among community-risk Thai participants. A fifth efficacy trial testing a DNA/ recombinant(r) Ad5 prime-boost combination is currently under way. We review the clinical trials of HIV vaccines that have provided insight into human immunogenicity or efficacy in preventing HIV-1 infection.

\section{CHALLENGES FOR HIV-1 VACCINES}

Several factors make development of a vaccine protective against HIV-1 infection a formidable scientific and technological challenge (Douek et al. 2006; Barouch 2008). Extraordinary viral diversity is perhaps the most intractable obstacle to vaccine development. Envelope amino acid sequence diversity among the nine subtypes $(A, B, C, D, F, G, H$, $\mathrm{J}$, and $\mathrm{K}$ ) and more than 35 circulating recombi- nant forms can vary up to $20 \%$ within a particular subtype and 35\% between subtypes (Walker and Korber 2001; Gaschen et al. 2002). Extremely rapid and error-prone replication yields a large number of mutant genomes, some of which are able to escape immune control (Richman et al. 2003; Goulder and Watkins 2004; Mascola and Montefiori 2010). Another major obstacle is the lack of clear immune correlates of protection in humans (Pantaleo and Koup 2004; Plotkin 2008). As natural immune responses

\footnotetext{
${ }^{3}$ The views expressed here belong solely to the investigators and are not to be construed to reflect the views of the Department of the Army, nor the Department of Defense.

Editors: Frederic D. Bushman, Gary J. Nabel, and Ronald Swanstrom

Additional Perspectives on HIV available at www.perspectivesinmedicine.org

Copyright (C) 2012 Cold Spring Harbor Laboratory Press; all rights reserved; doi: 10.1101/cshperspect.a007351

Cite this article as Cold Spring Harb Perspect Med 2012;2:a007351
} 
R.J. O'Connell et al.

against HIV fail to prevent infection or eradicate the virus, HIV-1 vaccine development cannot emulate the disease-free immune state. Candidate vaccine immunogenicity can be characterized, but these responses cannot be rationally weighted for further evaluation in the absence of correlates of protection. Broadly neutralizing antibodies (NAb) do occur rarely in HIV-1infected individuals (Simek et al. 2009; Zhou et al. 2010), and passive administration of high doses of monoclonal antibodies affords protection to simian human immunodeficiency virus (SHIV) infection in nonhuman primates (Baba et al. 2000; Mascola et al. 2000; Hessell et al. 2010). However, immunogens that elicit such antibodies have been elusive for many reasons including tolerance control and immunoregulation (Johnson and Desrosiers 2002; Haynes et al. 2005), sequestration of the epitope in the lipid membrane (Sun et al. 2008), and exposure of epitopes only transiently during viral entry (Frey et al. 2008). Cell mediated immunity also develops in most infected individuals in the form of cytotoxic T-lymphocyte (CTL) cell activity which suppresses HIV replication and produces $\beta$-chemokines but fails to eradicate infection (Cocchi et al. 1995; D’Souza and Harden 1996; Mackewicz et al. 1996). Finally, long-lived latent tissue reservoirs are established very early in infection, greatly complicating eradication of infection (Chun et al. 1997, 1998).

\section{GENERAL APPROACHES TO VACCINE DEVELOPMENT}

Prophylactic vaccines against HIV-1 have attempted to accomplish one of two goals: prevent establishment of infection through generation of NAb, or generation of T-cell responses that result in attenuation of pathogenesis once infection occurs (Douek et al. 2006; McMichael 2006). The latter approach has been referred to as "T-cell" vaccination (Korber et al. 2009). Whole inactivated HIV-1 vaccines (WIVs) have not been seriously considered for human vaccination largely owing to concerns that inactivation might be incomplete, especially when viral aggregates occur. Additional complicating factors include a loss of antigenicity seen with conventional virus inactivation strategies, relatively modest neutralization induced by WIVs using alternative inactivated approaches (Poon et al. 2005), and marginal protective efficacy in rhesus macaques (Lifson et al. 2004). Although live simian immunodeficiency virus (SIV) vaccine attenuated by deletion of the nef gene has shown protection against SIV infection (Daniel et al. 1992; Joag et al. 1998; Wyand et al. 1999), safety concerns preclude its development in humans. First, in vivo nef repair and evolution occurs in SIVinfected macaques (Whatmore et al. 1995), and pathogenicity is at least partially retained both in macaques infected with SIV $\Delta$ nef (Baba et al. 1995; Cohen 1997) and in humans infected with nef-deleted HIV-1(Mariani et al. 1996).

These considerations have directed most vaccine efforts toward newer strategies that employ synthetic envelope protein subunits or HIV-1 protein expression via recombinant viral vectors with HIV-specific inserts, or naked DNA. Heterologous prime-boost approaches are frequently used because of the early observation that such regimens often strengthen and broaden HIV-specific immune responses (Cooney et al. 1993; Excler and Plotkin 1997; Ranasinghe and Ramshaw 2009). Prime-boost strategies are not new to medical science: Knowledge that naturally occurring immune responses may be boosted has existed since Robert Koch showed that microbe-derived antigen provoked an immune response at injection sites in tuberculosis patients (Burke 1993). More than $100 \mathrm{NHP}$ and human clinical trials have evaluated prime-boost HIV-1 vaccine strategies (Paris et al. 2010). In this article, we focus on HIV preventive vaccine strategies that have progressed to at least phase II human testing (Table 1).

\section{MODELING HIV VACCINE DEVELOPMENT}

Studies evaluating chronically HIV-1-infected individuals have led to many important insights that inform vaccine development. For a complete discussion of HIV-1 pathogenesis, please refer to Lackner et al. (2011). 


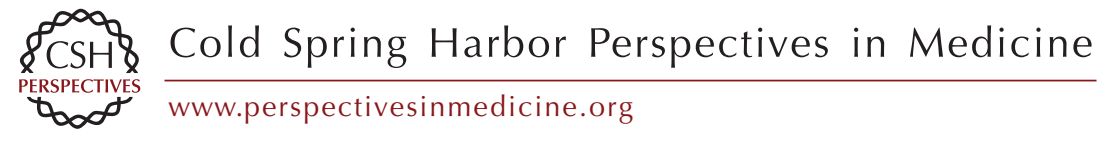

Table 1. Completed phase II and III human HIV-1 vaccine trials

\begin{tabular}{|c|c|c|c|c|c|c|c|}
\hline Category & Study protocol & Candidate vaccine & Phase & Volunteers & Location & $\begin{array}{c}\text { Year } \\
\text { published }\end{array}$ & Result \\
\hline Pox-protein & RV144 & $\begin{array}{l}\text { ALVAC-HIV vCP1521/AIDSVAX MN-CM244 } \\
\text { rgp120(CRF01_AE, B) }\end{array}$ & III & 16,403 & Thailand & 2009 & $31 \%$ efficacy \\
\hline Pox-protein & HVTN203 & ALVAC vCP1452/MN-GNE8 rgp120 (B) & II & 330 & US & 2007 & $\begin{array}{l}\text { Interferon- } \gamma \text { ELISpot in } 16 \% \text { of } \\
\text { volunteers }\end{array}$ \\
\hline Pox-protein & HIVNET 026 & ALVAC vCP1452/MN rgp120 (B) & II & 200 & Multinational & 2007 & Not immunogenic \\
\hline Pox-protein & $\begin{array}{l}\text { AVEG 202/ } \\
\text { HIVNET } 014\end{array}$ & ALVAC-HIV vCP205/SF2 rgp120 (B) & II & 420 & US & 2001 & $\begin{array}{l}\mathrm{CD} 8^{+} \mathrm{T} \text { cells in } 33 \% \text { of } \\
\text { volunteers }\end{array}$ \\
\hline DNA-pox & IAVI 010 & DNA-HIVA/MVA-HIVA (A) & IIa & 115 & East Africa & 2007 & $\begin{array}{l}\text { Rare interferon- } \gamma \text { ELISpot } \\
\quad \text { responses }\end{array}$ \\
\hline DNA-pox & HVTN 205 & GeoVax JS7 DNA/MVA HIV62 (B) & II & 225 & US, Peru, RSA & - & Ongoing \\
\hline DNA-Ad5 & RV 172 & $\begin{array}{l}\text { DNA (VRC-HIVDNA016-00-VP)/ } \\
\text { rAd5(VRC-HIVADV014-00-VP (A, B, and C) }\end{array}$ & I/IIa & 324 & East Africa & 2010 & $\begin{array}{l}\text { Interferon- } \gamma \text { ELISpot in } 63 \% \text { of } \\
\text { volunteers }\end{array}$ \\
\hline DNA-Ad5 & HVTN 204 & $\begin{array}{l}\text { DNA (VRC-HIVDNA016-00-VP)/ } \\
\text { rAd5(VRC-HIVADV014-00-VP (A, B, and C) }\end{array}$ & IIa & 480 & Americas, RSA & - & $\begin{array}{l}\text { Interferon- } \gamma \text { ELISpot in }>60 \% \\
\text { of volunteers }\end{array}$ \\
\hline DNA-Ad5 & HVTN 505 & $\begin{array}{l}\text { DNA (VRC-HIVDNA016-00-VP)/ } \\
\text { rAd5(VRC-HIVADV014-00-VP (A, B, and C) }\end{array}$ & $\mathrm{IIb}$ & 1350 & US & - & Ongoing \\
\hline DNA-Ad5 & $\begin{array}{l}\text { HVTN 502/ } \\
\quad \text { Merck } 023\end{array}$ & MRKAd5 HIV-1 gag/pol/nef (B) & $\mathrm{IIb}$ & 3000 & US & 2008 & $\begin{array}{l}\text { No efficacy; transient infection } \\
\text { risk }\end{array}$ \\
\hline DNA-Ad5 & HVTN 503 & MRKAd5 HIV-1 gag/pol/nef & $\mathrm{IIb}$ & 3000 & RSA & - & No efficacy \\
\hline Pox-protein & $\begin{array}{l}\text { ACTG 326; } \\
\text { PACTG } 326\end{array}$ & ALVAC vCP1452/AIDSVAX B/B & $\mathrm{I} / \mathrm{II}$ & 48 & US & 2005 & Safe, poorly immunogenic \\
\hline Peptide & ANRS VAC 18 & LIPO-5 & II & 156 & France & 2010 & $\mathrm{CD}^{+}{ }^{+}$responses in $>60 \%$ \\
\hline Protein-protein & AVEG 201 & rgp120/HIV-1 SF-2/MN rgp120 & II & 296 & US & 2000 & $\begin{array}{l}\text { NAb in } 87 \%, \text { DTH to gp } 120 \text { in } \\
59 \% \text { of volunteers }\end{array}$ \\
\hline AAV & IAVI A002 & $\operatorname{tgAAC09}$ & II & 84 & $\begin{array}{l}\text { RSA, Uganda, } \\
\text { Zambia }\end{array}$ & 2010 & $\begin{array}{l}\text { Interferon- } \gamma \text { ELISpot in } 25 \% \text { of } \\
\text { volunteers }\end{array}$ \\
\hline Protein & VAX 003 & AIDSVAX B/E & III & 2500 & Thailand & 2006 & No efficacy \\
\hline Protein & VAX 004 & AIDSVAX B/B & III & 5400 & US & 2005 & No efficacy \\
\hline
\end{tabular}

Shown are completed clinical HIV vaccine trials grouped by vaccine types (Category).

Pox, recombinant poxvirus-vectored vaccine; DNA, deoxyribonucleic acid; Ad5, recombinant adenovirus 5-vectored vaccine; US, United States; RSA, Republic of South Africa; Nab, neutralizing antibodies; DTH, delayed type hypersensitivity. 
R.J. O'Connell et al.

\section{Acute Infection}

HIV infection acquired sexually begins in $\mathrm{CD} 4^{+}$ $\mathrm{T}$ cells or macrophages in vaginal or rectal mucosa and remains confined to mucosa or regional lymphoid tissue for a few days during the "eclipse phase" before exponential replication of virus in plasma and establishment of the reservoir (McMichael et al. 2010). Unfortunately, immune responses elicited by HIV-1 infection fail to prevent infection. However, many insights from these well-characterized adaptive and innate responses offer hope that optimized vaccine-induced responses may be protective. Studies of acutely HIV-1 infected humans have shown that the majority of sexually acquired infections are caused by a single transmitted/founder $(\mathrm{T} / \mathrm{F}$ ) virus (Keele et al. 2008; Abrahams et al. 2009; Salazar-Gonzalez et al. 2009). Unlike viruses circulating in chronically infected humans, $\mathrm{T} / \mathrm{F}$ viruses are more likely to be CCR5-tropic and are less macrophage-tropic (Salazar-Gonzalez et al. 2009). Initial viral uniformity could make the virus more easily neutralized if an effective immune response were present at the time of exposure. Adaptive cellular $\left(\mathrm{CD}^{+}\right)$immune responses drive both viral suppression and diversity through escape mutants (Goonetilleke et al. 2009; Treurnicht et al. 2010). Similarly, HIV-specific antibody responses, which typically mature over time, significantly shape the generation of neutralization escape mutants but fail to neutralize contemporaneous strains (Richman et al. 2003; Wei et al. 2003; Moore et al. 2009).

\section{Nonhuman Primate Models}

Nonhuman primate (NHP) models have provided important insights into HIV-1 vaccine development. Four models utilizing different viruses or host species have been used: HIV-1/ chimpanzee, HIV-2/macaque, SIV/macaque, and SHIV/macaque. The SIV/macaque and $\mathrm{SHIV} /$ macaque models are currently most commonly used because of low levels of HIV replication, prolonged time to progression, and high cost of HIV-2 and chimpanzee models (Franchini et al. 2004). NHP experiments inform vaccine development through elegant experiments aimed at elucidation of SIV or SHIV pathogenesis or vaccine performance. An SIV-macaque study showed increased survival, reduction in viremia, and preservation of central memory $\mathrm{CD}^{+}{ }^{+} \mathrm{T}$ lymphocytes following delivery of a plasmid DNA prime followed by type 5 Adenovirus vector boost vaccine (Letvin et al. 2006). This study, along with human immunogenicity data from phase I studies, raised enthusiasm for an ongoing phase IIB efficacy study of these vaccines (ClinicalTrials.gov, NCT00865566), in the HIV Vaccine Trial Network (HVTN) 505 protocol. A similar approach using a SHIV/macaque model (Shiver et al. 2002) failed to predict the lack of efficacy in a phase IIB evaluation of the Merck Ad5 gag/pol/nef vaccine (Buchbinder et al. 2008). This vaccine failed to show postinfection viremic control in a SIV challenge model (Casimiro et al. 2005). Unfortunately, there are no animal models that accurately predict efficacy in humans. High-dose challenge NHP models are potentially confounded by high SIV challenge doses used to achieve $100 \%$ infection rates after a single exposure in placebo animals (McDermott et al. 2004). Repeated mucosal challenges with a lower dose of virus (10-50 $\mathrm{TCID}_{50}$ ) may more accurately approach human exposure conditions, but such studies remain to be correlated with human clinical trial outcomes.

\section{DNA AND PROTEIN SUBUNIT VACCINE TRIALS}

\section{Protein Subunit Alone}

Initial clinical trials of candidate HIV vaccines in the late 1980s and early 1990s attempted to follow the template for hepatitis $B$ vaccine: Use recombinant subunits or synthetic peptide fragments to elicit neutralizing antibodies against viral antigens expressed on the virion surface. For HIV-1, these are the Env proteins gp120 and gp41. These antigens typically elicit strong binding antibody, limited neutralizing antibody (Nab) and $\mathrm{CD}^{+}$, but not $\mathrm{CD}^{+}$, T-cell responses (Pantophlet and Burton 2006). 
Following a phase I/II trial that showed safety and immunogenicity (Belshe et al. 1994), the first phase III efficacy trial of a prophylactic HIV-1 vaccine (VAX 004) investigated a recombinant $\mathrm{HIV}-1$ envelope glycoprotein subunit (rgp120) derived from MN, a laboratory-grown strain, and a second envelope derived from a clade B primary isolate (GNE8) (AIDSVAX B/B') in alum adjuvant. Study participants were men who have sex with men and women at high risk for heterosexual transmission of HIV-1 from 61 sites in the United States, Puerto Rico, Canada, or the Netherlands (Harro et al. 2004; Flynn et al. 2005). Participants received vaccine or placebo at months 0 , $1,6,12,18,24$, and 30 . Infection rates among the 3598 vaccinees and 1805 placebo recipients were similar at $6.7 \%$ and $7.0 \%$, respectively. There were no differences in postinfection secondary end points including viral load, $\mathrm{CD}^{+}{ }^{+}$T-cell count, time interval to initiation of antiretroviral therapy, or genetic characteristics of the infecting virus. Vaccine induced binding antibody responses were inversely correlated with risk of infection. For all eight antibody variables, the mean responses tended to be slightly higher in uninfected vaccinees than in infected vaccinees, suggesting that such antibody responses either (1) caused both increased (low responders) and decreased (high responders) risk of HIV acquisition or (2) represented a correlate as opposed to causative mechanism for enhanced HIV-1 acquisition. There was some suggestion that there were both higher antibody titers and protection in AfricanAmerican subjects, but incorporation of a correction for multiple sampling diminished this finding. Neutralizing antibodies did not correlate with infection incidence (Gilbert et al. 2005).

Following the demonstration of safety and immunogenicity in a phase I/II trial in Bangkok, Thailand (Pitisuttithum et al. 2004), a second phase III efficacy trial of a vaccine candidate was undertaken (VAX003). This study represented the first efficacy trial conducted in a developing country, and it was the first to exclusively study an intravenous drug user (IDU) population. The vaccine contained two different rgp120 antigens, one from subtype B $\mathrm{MN}$, and the other from a primary isolate CRF_AE (A244) produced in Chinese hamster ovary (CHO) cells in alum adjuvant. A total of 2546 IDUs were enrolled between March 1999 and August 2000 and received vaccine or placebo at months $0,1,6,12,18,24$, and 36 . Adverse events were rare and occurred with equal frequency among vaccine and placebo recipients. Vaccine efficacy was estimated at $0.1 \%$ (95\% CI, $-30.8 \%$ to $23.8 \%$ ), and no effect was observed on secondary end points (Pitisuttithum et al. 2006; Pitisuttithum 2008).

Among 2099 uninfected subjects in phase I and II trials of Env-based subunit AIDS vaccines, 23 were diagnosed with intercurrent HIV-1 infection. There were no significant differences in secondary end points, including virus load, CD4 lymphocyte count, or V3 loop amino acid sequence (Graham et al. 1998).

Further nonprespecified analyses of Vax 004 antibody-directed cell-mediated viral inhibition (ADCVI) showed an inverse correlation between ADCVI levels and HIV acquisition. This effect was influenced by Fc- $\gamma$ IIa and IIIa polymorphisms (Forthal et al. 2007). More recently, Gilbert et al. reported low levels of neutralizing antibody against Tier 2 isolates in Vax 004 (Gilbert et al. 2010); however, when the same data are analyzed using two different assays (Monogram and TZM-bl), there appeared to be an inverse correlation between breadth of (low-level) Tier 2 neutralization and infection (B Korber, unpubl.).

\section{DNA Prime Protein Subunit Boost}

Strategies employing DNA prime followed by protein boost have only been studied in a single published phase I human trial. A polyvalent DNA prime vaccine containing five plasmids each encoding a codon-optimized protein including gp120 sequences from subtypes A, B, C, and E, as well as a sixth plasmid encoding a subtype C gag gene was performed. Protein boost components included equal parts of five gp120 proteins matching those used in DNA prime components formulated with QS-21 adjuvant and excipient cyclodextrin (Wang 
R.J. O'Connell et al.

et al. 2008). DNA vaccination was administered in two different doses intramuscularly (IM), as well as in one dose intradermally (ID). The vaccine strategy elicited cross-subtype HIV-specific $\mathrm{T}$ cell responses as well as high titer serum antibody responses against HIV-1 viruses with diverse genetic backgrounds. These results were tempered by observations of delayed type hypersensitivity in $43 \%$ of subjects following protein vaccination, and two cases of vasculitis temporally related to inoculation with recombinant Env protein + QS21 adjuvant (Kennedy et al. 2008).

Early naked DNA plasmid vaccines given alone were poorly immunogenic and responses lacked durability (MacGregor et al. 1998, 2000, 2002; Wang et al. 1998; Roy et al. 2000). Such observations have led to pursuit of alternative strategies to enhance immune responses (Abdulhaqq and Weiner 2008), and contemporary strategies typically use DNA vaccines as a "prime" with a heterologous boost. Electroporation is a promising approach that has been used to enhance in vivo transfection rates in nonhuman primates (Rosati et al. 2008; Patel et al. 2010) and more recently in several phase I HIV-1 preventive DNA vaccine human trials (Vasan et al. 2009; clinicaltrials.gov NCT00991354 and NCT01260727).

\section{PEPTIDE VACCINE TRIALS}

Several synthetic peptide constructs have been investigated as potential preventive HIV-1 vaccines. Sequences from the envelope V3 loop induce $\mathrm{Nab}$ in some laboratory animals but were tolerogenic in macaques and chimpanzees. An octameric V3 multiple antigen peptide formulated in alum was found to be safe but generated neither consistent nor robust lymphoproliferative responses in human volunteers (Kelleher et al. 1997). Peptides do not usually induce a class I-restricted $\mathrm{CD}^{+}$response in vivo, but some lipopeptides elicit such a response (Deres et al. 1989; Deprez et al. 1996). Building on this concept, a phase II human trial evaluated HIV-LIPO-5 vaccine (five long peptides, Gag17-35, 253-284, Pol325-355, Nef66-97, and 116-145, containing multiple
$\mathrm{CD}^{+}$and $\mathrm{CD}^{+}{ }^{+}$epitopes, coupled to a palmitoyl tail) in 132 volunteers. Vaccination, which was given IM at one of three doses at weeks 0 , 4,12 , and 24 , elicited $\mathrm{CD}^{+}$responses as measured by IFN- $\gamma$ ELISpot in two-thirds of vaccine recipients regardless of dose, and $\mathrm{CD}^{+}{ }^{+}$responses as measured by PBMC lymphoproliferation in approximately half of vaccine recipients regardless of dose (Salmon-Céron et al. 2010). Future studies will likely incorporate lipopeptides in prime-boost regimens.

\section{ADENOVIRAL VECTOR VACCINE TRIALS}

DNA and adenovirus constructs have been some of the most extensively tested in the NHP model. Enthusiasm for Merck DNAAd5 was generated by the comparative study by Shiver et al. in which macaques that received either DNA-Ad5 or Ad5 alone, and were challenged with a homologous SIV with an HIVderived envelope (SHIV)89.6P virus, controlled viral replication better than monkeys that received rMVA (Shiver et al. 2002). A postinfection viral load reduction was not seen when SIVmac239 was the challenge virus (Casimiro et al. 2005). The results of the Merck Step trial (discussed in the following paragraphs) have led to a reevaluation of the NHP challenge model, in particular, questions about dose (low vs. high dose), route (intravenous vs. mucosal), SHIV versus SIV challenge, virus challenge stock (single clone vs. "swarm," heterologous vs. homologous), as well as end points (Fauci et al. 2008; Watkins et al. 2008). Recently, statistically significant differences in control of viral replication after challenge have been observed in the macaque model using a heterologous challenge with SIVsmE660 after vaccination with DNA-Ad5 that expresses all HIV proteins except Env from SIVmac239 (Wilson et al. 2009). DNA-Ad5 SIV-based vaccines protected against an SIVsmE660 acquisition after lowdose intrarectal challenge (Letvin et al. 2011). Adenovirus serotypes that are less commonly associated with human disease have also recently been developed to overcome problems with preexisting immunity, and Ad26 and 35 vaccines are now in a Phase I clinical trial 
(Baden et al. 2009). Results from NHP challenge studies are encouraging-particularly the strategy of priming with Ad5 and boosting with Ad26, which was associated with a $2.4 \mathrm{log}$ reduction in set-point viral load and improved survival compared with control animals (Liu et al. 2009).

The most extensively tested of the adenoviral vector vaccine candidates in human trials is Merck's replication-defective Ad5, containing clade B gag, pol, and nef gene inserts. This candidate was advanced to a Phase IIb efficacy evaluation that was stopped at a scheduled interim analysis when it was apparent that there was no effect on postinfection viral RNA level (Buchbinder et al. 2008), despite demonstration of apparent immunogenicity in Phase I clinical trials and evidence of viral load control in the SHIV / NHP model (Shiver et al. 2002; Casimiro et al. 2003; Wilson et al. 2006; Priddy et al. 2008; Harro et al. 2009; Asmuth et al. 2010). Although mechanisms underlying failure of this vaccine remain elusive, one explanation is that this homologous vector vaccine, which elicits frequent IFN- $\gamma$ ELISpot responses (77\% of vaccinees overall) when given in three doses, generates a limited breadth of antigen-specific responses (McElrath et al. 2008). Likewise, the absolute level of IFN- $\gamma$ ELISpot may have been too low, or given the inferior IFN- $\gamma$ ELISpot generation by the ALVAC + AIDSVAX B/ E combination, the ELISpot assay may not measure relevant responses. Intense study evaluated initial vaccine-related enhancement of infection among a subgroup of anti-Ad5 positive uncircumcised men who have sex with men (MSM) (Buchbinder and Duerr 2009; D'Souza and Frahm 2010). Extended followup analyses (Benlahrech et al. 2009; MasekHammerman et al. 2010) have indicated that increased risk of acquisition decreased over time. The significance and potential mechanism of vaccination-enhanced acquisition among uncircumcised men is unclear, therefore a cautious approach has been taken with Ad5-vectored $\mathrm{gag} / \mathrm{pol} /$ nef vaccines, especially in uncircumcised MSM (Duerr et al. 2010).

The NIH/NIAID Vaccine Research Center has also developed a DNA-rAd5 prime-boost regimen, which has been extensively tested for safety and immunogenicity, and a Phase IIb efficacy, test-of-concept trial is ongoing in the United States (HVTN 505) among circumcised men who have sex with men and lack preexisting antivector-NAbs. The first DNA-rAd5 combination consisted of four separate DNA plasmids (VRC-HIVDNA009-00-VP): One plasmid with gene inserts for gag (clade B strain HXB2), pol (clade B NL4-3), and nef (clade B, PV22) with mutations in gag and pol to prevent enzymatic activity, creating a fusion protein product that does not produce pseudoparticles. Env genes from clades A (92RW020), B (HXB2), and C (97ZA012) were truncated immediately downstream from the transmembrane domain of gp41, along with other deletions, to create three gp145-expressing plasmids. For the rAd5 boost (VRC-HIVADV014-00VP), four separate vectors were produced with the same inserts (clade/strain matched) expressing a Gag/Pol polyprotein along with gp140 versions of Env. Nef was not included in Ad5 as the vectors were not stable. Separate Phase I dose-ranging trials of each of these products showed that the plasmid DNA was similarly immunogenic at the $4(n=20)$ or $8 \mathrm{mg}(n=15)$ doses with $100 \%$ and $93 \%$ with $\mathrm{CD}^{+}{ }^{+}$responses by ICS, respectively, and $35 \%$ and $33 \%$ with $\mathrm{CD}^{+}$responses, respectively, with both T-cell subsets exhibiting more Env-specific responses. The rAd5-vectored HIV-immunogens generated ELISpot responses in 22 out of 30 patients (73\%), with 28 out of 30 patients having a detectable $\mathrm{CD} 4^{+}$response and 18 out of 30 patients a $\mathrm{CD}^{+}$response by ICS at week 4 (peak immunogenicity) after a single IM dose, and mostly Env-specific. Although no NAb were detected in either the DNA or rAd5 trials, Env-specific binding antibody responses measured using ELISA were detected in $50 \%$ and $71 \%$ of rAd5 and DNA recipients, respectively (Catanzaro et al. 2006, 2007; Graham et al. 2006).

These constructs were subsequently tested in three Phase IIa trials, IAVI V001, HVTN 204, and RV172 (Kibuuka et al. 2010). In the RV172 study, the VRC DNA (VRC-HIVDNA016-00-VP) tested was a six-plasmid mixture 


\section{R.J. O'Connell et al.}

encoding HIV env from subtypes A, B, and C, and subtype $\mathrm{B}$ gag, pol, and nef, and VRCHIVADV014-00-VP. Volunteers were randomized to receive either $10^{10}(n=24)$ or $10^{11}$ $(n=24)$ particle units (PUs) of rAd5 on day 0 only; 4 mg of DNA at 0,1 , and 2 months, followed by rAd5 at either $10^{10}(n=114)$ or $10^{11}$ PUs $(n=24)$ boosting at 6 months. HIVspecific T-cell responses were detected in 63\% of vaccinees. ELISpot responses for DNA prime with low-dose $(63 \%)$ or high-dose $(60 \%)$ rAd5 were similar-positive responses were predominantly to Env peptides, followed by Pol or Gag, regardless of the immunization regimen. The high-dose rAd5 boost had the highest frequency of responders to all three antigens tested (Env, Gag, or Pol), whereas responses were approximately equal for the other immunization groups for two antigens $(20 \%-26 \%)$. Preexisting Ad5-NAbs did not appear to affect the frequency or magnitude of $\mathrm{T}$-cell responses in the prime-boost vaccinees. Response rates in participants that received rAd5 alone were lower, but not statistically significant.

\section{Rare Serotype Ad Vectors}

Antivector immunity against adenovirus vectors varies by population and serotype. Ad5 and Ad35 seropostivity was detected in $60 \%$ and $7 \%$, respectively, in individuals at risk for AIDS, respectively, living in the Netherlands, and $90 \%$ vs. $20 \%$ among those living in subSaharan Africa (Kostense et al. 2004). Vector neutralization threatens to attenuate immunogenicity, prompting construction of vectors using Ad serotypes that have lower frequencies of natural infection in humans, such as Ad36 and Ad26 (Barouch 2010).

\section{POXVIRUS AND PROTEIN SUBUNIT PRIME- BOOST VACCINE TRIALS}

Poxviruses have properties that make them excellent expression systems. Characteristics such as large capacity for integration of foreign DNA (more than 25,000 base pairs for vaccinia virus [VV]) and cytoplasmic gene expression are possessed by members of the poxviridae family. Successful recombinant gene expression using poxvirus was first shown in 1982 and has been used for such diverse activities as analysis of protein structure/function relationships, protein processing and intracellular trafficking, antigen presentation, and the determinants of cellular and humoral immunity, and live recombinant vaccines. Meaningful differences among poxviridae include host specificity and susceptibility to antivector host immunity (Paoletti 1996; Carroll and Moss 1997).

\section{Vaccinia Vectors}

Modified Vaccinia Ankara (MVA) was initially developed near the end of the smallpox eradication program by the technique of passaging virus about 500 times on primary chicken embryo fibroblasts (Franchini et al. 2004). Multiple resultant genetic deletions have rendered MVA unable to replicate in most mammalian cells, which is a likely explanation for its excellent safety record: It was assessed as a smallpox vaccine in over 120,000 recipients in Germany without significant adverse reactions. Its large genome renders it amenable to genetic manipulation, making it an ideal candidate vector for vaccine development (Moss 1991; Moss et al. 1996; Blanchard et al. 1998; Sutter and Staib 2003).

Macaque-SIV studies of DNA followed by MVA-vectored boost vaccination showed induction of CTL responses, primarily to a single SIV gag epitope (Hanke et al. 1999; Allen et al. 2000). Given alone IM, MVA-based vaccines have been shown to be safe and immunogenic in human clinical trials (Cebere et al. 2006; Dorrell et al. 2007; Peters et al. 2007; Jaoko et al. 2008). Antivector immunity is an important consideration: Many older adults as well as most members of the U.S. military have been inoculated with vaccinia and thus have at least some degree of antivaccinia immunity.

The first report of immunogenicity data for using prime-boost DNA/MVA vaccine approach evaluated pTHr-HIVA plasmid DNA and MVA-HIVA prime-boost combination, after initial Phase I safety testing (Mwau et al. 2004; Cebere et al. 2006). The HIVA immunogen contained consensus clade A Gag p24/p17 
sequences and a string of CTL epitopes inserted into plasmid DNA, and the same immunogens as a transgene insert in recombinant MVA (rMVA). Safety was first shown in several small trials (IAVI 001, IAVI 003 and IAVI 005), followed by Phase I/II studies. Only one antibody response to $\mathrm{p} 24 / \mathrm{p} 17$ was detected in any of the participants in these studies (Mwau et al. 2004; Cebere et al. 2006; Jaoko et al. 2008). In the IAVI 006 study, 119 volunteers were randomized into several arms and received pTHr-HIVA DNA in a dose of $0,0.5$, or $2.0 \mathrm{mg}$ in two doses IM, followed by two doses of $5 \times 10^{7}$ rMVA after 4 or 16 weeks. Using a fresh peripheral blood mononuclear cell (PBMC) IFN- $\gamma$ ELISpot assay, less than $15 \%$ of vaccine recipients had transient HIV-specific Gag responses, with no significant effect of DNA priming observed (Hanke et al. 2007; Guimaraes-Walker et al. 2008). In IAVI 016, 24 volunteers received either two doses of rMVA alone at the higher dose of $2.5 \times 10^{8}$ plaque-forming units ( $\mathrm{pfu}$ ) or two doses of pTHr-HIVA DNA at a higher dose of $4 \mathrm{mg}$ (Casimiro et al. 2003; Goonetilleke et al. 2006; Peters et al. 2007; Baden et al. 2009). In this study, immunomonitoring was conducted by ex vivo ELISpot, a "cultured" ELISpot using a 10-d, peptide-stimulated PBMC expansion step, and polyfunctional or multicolor flow cytometry. No antigen-specific responses were detected by the validated ex vivo ELISpot in the rMVA-only group, while four of eight in the DNA-rMVA group had responses. In the "cultured" ELISpot assay, five of eight in the rMVA-only group had responses, while all of those who received DNA-rMVA had Gag-specific responses. This modified ELISpot format detected predominantly $\mathrm{CD} 4^{+}$T-cell responses, with two vaccinees having $\mathrm{CD} 8^{+}$ responses, which were of greater magnitude and breadth in those who received the DNArMVA combination compared with the two doses of rMVA. Larger trials at these higher doses are ongoing (IAVI 2010).

Another DNA-MVA prime-boost Phase I study, HIVIS 02, has been conducted. This study utilized plasmid DNA constructs developed at the Karolinska Institute, and the Walter Reed Army Institute of Research/
National Institutes of Health (WRAIR/NIH)produced recombinant MVA-CMDR (Chiang Mai Double Recombinant), which has inserts based on CRF01_AE isolates from Thailand that express gp150 (CM235), gag and pol, with a deleted integrase and nonfunctional reverse transcriptase (CM240). MVA-CMDR was shown to be safe and immunogenic in a separate Phase I trial (Currier and de Souza 2009). A total of 40 healthy HIV-negative participants were randomized into four groups ( $n=10$ per group) and injected with seven DNA plasmids expressing subtypes A, B, and C gp160 env; B rev; subtype A and B p17/p24 gag, and clade B rt-mut. The DNA priming dose was administered ID or IM with or without recombinant granulocyte-macrophage colony-stimulating factor (GM-CSF) using the Biojector 2000. A single boost of MVA-CMDR was given 6 months after the last DNA injection at either $10^{7} \mathrm{pfu}$ ID or $10^{8} \mathrm{pfu}$ IM. Eleven of 37 (30\%) had positive ELISpot after DNA alone, whereas significant boosting was observed after MVA-CMDR with 34 of 37 (92\%) vaccinees responding (32 to Gag and 24 to Env). One mg of DNA administered ID was as effective as $4 \mathrm{mg}$ of DNA IM as a prime for the MVA-CMDR boost. In addition, $68 \%$ had an IL-2 ELISpot response and 92\% a HIV-1specific lymphocyte proliferation assay (LPA) response. These results were confirmed in a second study conducted in Tanzania (Aboud et al. 2010). A comparison of these DNA vectors delivered by Biojector and electroporation with subsequent rMVA boosting will evaluate the role of DNA delivery route (clinicaltrials.gov NCT01260727).

The GeoVax clade B DNA-MVA was tested in HVTN 065. Volunteers received IM DNA and MVA that expressed clade B Gag, Pol, and Env, with DNA given at 0 and 2 months and boosted at months 4 and 6 with MVA. Both low- $(0.3 \mathrm{mg}$ of DNA and 107 of the $50 \%$ tissue culture infective dose [TCID50] of MVA) and high-dose (3 mg of DNA and 108 TCID50 of MVA) formulations were tested. Preliminary results showed similar T-cell responses in lowand high-dose groups. In the high-dose group, $75 \%$ of volunteers had CD4 and $37 \%$ had 
R.J. O'Connell et al.

CD8 T-cell responses. Cosecretion of IL-2 and IFN-g was observed in $82 \%$ of CD4 and $67 \%$ of CD8 responses at the peak immunogenicity time point (Robinson et al. 2008). Additional DNA/MVA candidates based on subtype $\mathrm{C}$ (TBC-M4 MVA) and recombinant $\mathrm{B}^{\prime} / \mathrm{C}$ antigens (ADVAX DNA and ADMVA) have completed Phase I testing, but none in combination. ADVAX DNA given alone at 0,1 , and 3 months showed ELISpot responses in four of 12 high-dose recipients, whereas the MVA constructs (given IM at 0,1 , and 6 months) were more immunogenic, with ELISpot positivity in $60 \%-100 \%$ of vaccine recipients at the highest dose given (Ramanathan et al. 2009; Vasan et al. 2010a,b).

Despite initially disappointing results with the DNA-MVA prime-boost approach (Guimaraes-Walker et al. 2008), more recent studies are promising. Effects of MVA boost appear consistent with differences in immunogenicity probably because of DNA priming and dose (Hanke et al. 2007). One concern with using MVA as a vector is the presence of preexisting immunity to vaccinia, which may affect the magnitude and quality of immune responses, as shown with recombinant Ad5 vaccine vector (Priddy et al. 2008; Harro et al. 2009). However, data from the HIVIS-02 study indicate that only the magnitude of the response was attenuated, whereas the frequency of responders was maintained in those with preexisting vaccinia immunity (Gudmundsdotter et al. 2009; Barouch 2010).

NYVAC was derived from VC-2, a plaque-cloned isolate of the COPENHAGEN vaccinia strain. NYVAC construction entailed deletion of 18 open reading frames encoding for replication competency in mammalian cells and virulence factors (Tartaglia et al. 1992).

The EuroVacc 02 Phase I trial evaluated recombinant DNA and NYVAC, which express matched immunogens containing gag, pol, env, and nef sequences from a Chinese clade B and $\mathrm{C}$ recombinant virus isolate, 97CN54 (CRF70_B/C'). Forty volunteers received DNA $\mathrm{C}$ or placebo on day 0 and at week 4 , followed by NYVAC C boosting (20 received DNA/ NYVAC) at weeks 20 and 24. A total of $90 \%$ showed IFN- $\gamma$ ELISpot responses compared with 33\% who received NYVAC C alone. T-cell responses were of relatively high magnitude, with $\mathrm{CD}^{+}$(16 of 18 assessed) more frequent than $\mathrm{CD}^{+}$responses (eight of 16). Responses were skewed toward Env (91\% of vaccinees), with $48 \%$ responding to Gag, Pol, or Nef. Responses after NYVAC boost compared with NYVAC alone suggest that DNA priming was occurring, even when no immune response was detected after the second dose of DNA (Harari et al. 2008). Induced T cells were typically polyfunctional, with $60 \%$ exhibiting two to three functions, and both $\mathrm{CD}^{+}$and $\mathrm{CD} 8^{+}$ $\mathrm{T}$ cells typically expressing IFN- $\gamma$, IL-2, and TNF- $\gamma$. Prime-boost regimens with DNA and poxvirus vectors appear to induce polyfunctional T-cell responses that are biased toward Env-specific T-cell responses, with a predominance of $\mathrm{CD}^{+}{ }^{+}$over $\mathrm{CD} 8^{+} \mathrm{T}$-cell responses.

\section{Canarypox Vectors}

ALVAC is a recombinant canarypox virus (CPV)-based vector that functions as an immunization vehicle by expressing gene products in the absence of productive viral replication (Tartaglia et al. 1992). Although there are no licensed ALVAC-based human vaccines, commercial production feasibility is clearly shown by current marketing of five licensed veterinary canarypox-based vaccines: Recombitek (Canine distemper), Purevax (rabies[cats]), Recombitek WNV (West Nile [equine]), Eurifel (feline leukemia), and Proteqflu (influenza[horses]) (Merial 2010). Because CPV is a bird pathogen, canarypox recombinant vectors infect but are unable to replicate in humans, predicting that they will not disseminate in vaccine recipients nor be transmitted to unvaccinated contacts (Taylor et al. 1988; Baxby and Paoletti 1992). In both guinea pig and macaque models, gp160 MN/LAI-2 significantly boosted antibody responses primed with ALVAC-HIV (Excler and Plotkin 1997; Jaoko et al. 2008). ALVAC-HIV-1 expressing homologous vaccine native Env proteins protected macaques from high-dose mucosal challenge, and this protection was better when gp120 antigen was 
included in the vaccine (Pialoux et al. 1995; Excler and Plotkin 1997). ALVAC-SIV given to neonatal macaques protected against low dose SIV challenge in milk; interestingly, an MVA-SIV vaccine developed better ELISpot responses but did not protect (Van Rompay et al. 2005).

Multiple HIV-1 inserts have been inserted into ALVAC vectors, yielding extensive safety and immunogenicity data in humans (Gilbert et al. 2003; de Bruyn et al. 2004). Phase I human trials with recombinant canarypox vectors have shown induction of $\mathrm{CD}^{+}$CTL (notably these are after in vitro stimulation; when direct ex vivo IFN-g or CD107 expression is measured, $\mathrm{CD}^{+}$CTL are not identified). However, only $15 \%-30 \%$ of subjects have such responses at any given time postvaccination (Belshe et al. 1998, 2001; Clements-Mann et al. 1998; Evans et al. 1999; Salmon-Céron et al. 1999). Three recombinant ALVAC HIV-1 vaccines have advanced to Phase II studies.

ALVAC-HIV vCP205 expresses four gene products: Gag p55 protein from the HIV-1 LAI strain, p15 protein, a portion of the protease gene from the HIV-1 LAI strain, a portion of gp120 from the HIV-1 MN strain, and the anchoring transmembrane region of gp41 from the HIV-1 LAI strain (Paris et al. 2010). This recombinant vector was studied in a phase II trial conducted in the US among 60 study participants at lower risk for HIV-1 infection and 375 individuals at higher risk for HIV-1 infection. ALVAC-HIV vCP205 was given with or without an SF-2 rgp120 boost at 0, 1, 3, and 6 months (Belshe et al. 2001). More than $90 \%$ of combination regimen recipients developed $\mathrm{Nab}$ responses against homologous TCLA virus, and approximately one-third of those who received vCP205-containing regimens developed anti-HIV CTL responses, without differences in immune responses among the higher and lower risk groups.

More complex ALVAC vectors, vCP1433 and vCP1452, were designed to provide better gene expression and more durable $\mathrm{CD} 8^{+}$CTL responses. Both express gag, protease, nef, and pol genes, and a part of the env gene expressing the gp120 and anchoring region of gp41. The
ALVAC vCP1452 vector was modified by insertion of two vaccinia virus-coding sequences (E3L and K3L) to enhance expression efficiency in ALVAC-infected human cells. In large, phase II studies, HVTN 203 and HIVNET 026, vCP1452 was boosted with the bivalent rgp120containing sequence from the clade B primary isolate GNE8 as well as MN. Cellular immunogenicity in this study was not deemed sufficient to proceed with a planned Phase III immune correlates trial (Russell et al. 2007).

Two Phase I/II trials of vCP1521, which is similar to vCP205 except for a different env, 92Th023 gp120 (CRF01_AE), substituted for $\mathrm{MN}$, in combination with three different subunit boosts have been conducted in Thailand. In RV132 (vCP1521 + oligomeric rgp160 92TH023/polyphosphazene or rgp120 CM235/SF2/MF59), the majority of recipients $(68 \%-93 \%)$ developed either SF2, TH023 or CM235 lymphoproliferative responses to gp120 antigens. In RV132, NAb to the TCLA subtype E strain NPO3 was found in $84 \%$ and $89 \%$ of recipients of vCP1521 + gp160 TH023 or gp120 CM235/SF2, respectively. In total, $96 \%$ and $100 \%$ of vCP1521 + gp160 TH023 and vCP1521 + gp120 CM235/SF2 prime-boost recipients had NAb against any subtype E-adapted HIV-1, respectively. Neutralization of homologous and heterologous laboratory-adapted strains of HIV-1 was observed for the majority of vaccine recipients in both prime-boost arms. Cross-neutralization of SF2 by recipients of oligomeric gp160 (27\%) was also observed. The NAb response observed for subjects boosted with bivalent gp120 B/ CRF01_AE was similar to a previous clinical trial of these antigens among Thai volunteers (Pitisuttithum et al. 2003). In that study, 84\% and $96 \%$ of volunteers who received both vaccine antigens had NAb to NPO3 and SF2, respectively. Some data suggest that oligomeric antigens may be more likely to induce relevant $\mathrm{NAb}$, although this was not seen in relation to the heterologous CM244 strain in a PBMCbased neutralization assay (Fouts et al. 1997; VanCott et al. 1997). HIV-specific CD8 ${ }^{+}$CTLs were detected in $11 \%$ and $25 \%$ of primeboost recipients in the gp160 TH023 + gp120 
R.J. O'Connell et al.

CM235/SF2 arms of RV132, respectively (Thongcharoen et al. 2007).

In $\mathrm{RV} 135,58 \%$ and $67 \%$ of persons receiving vCP1521 plus high- or low-dose rgp120 (MN/A244) in alum developed A244-specific proliferative responses, whereas $71 \%$ had a $\mathrm{NAb}$ response against subtype E-adapted HIV1. HIV-specific $\mathrm{CD}^{+}$CTLs were identified in $23 \%$ of vaccinees receiving either boost (Nitayaphan et al. 2004). Significant ADCC activity was also observed in over $85 \%$ of vaccine recipients to either clade B or CRF01_AE gp120 (Karnasuta et al. 2005). The vCP1521 prime and highdose $300 \mu \mathrm{g}$ of MN and $300 \mu \mathrm{g}$ of A244 boost was chosen for use in a Phase IIb efficacy trial, RV144.

\section{RV144-Proof of Concept for Protective Efficacy}

As neither the oligomeric gp160 92TH023 or the bivalent gp120 B/E vaccine were available for further testing, the vaccine combination in RV135, which had passed the predetermined immunogenicity criteria for advancement, was selected for efficacy testing. The Thai "Phase III" trial, RV144, provided the first evidence that an HIV vaccine could provide protective efficacy (Rerks-Ngarm et al. 2009). The modified intent-to-treat analysis (excluding those randomized, but HIV-infected at the first vaccination visit) showed 31.2\% efficacy (95\% CI: $1.1,52.1 ; p=0.04$ ) after 42 months of followup after vaccination with ALVAC vCP1521 at 0, 1,3 , and 6 months with boosting with AIDSVAX B/E rgp120 at 3 and 6 months. Although not included in the prespecified analysis plan, vaccine efficacy appeared to be higher (60\%, 95\% CI 22,80) at 12 months postvaccination, suggesting an early, but nondurable, vaccine effect (Michael 2009). In a subset of HIV-negative volunteers who completed all immunizations, $20 \%$ had $\mathrm{CD}^{+}$ELISpot responses to Gag or Env. Intracellular cytokine staining showed predominantly $\mathrm{CD}^{+}{ }^{+}$responses favoring Env over Gag (34\% vs. $1.4 \%$ ). Lymphoproliferation to gp120 was approximately $87 \%$ for MN and 90\% for A244. Few Nab were identified. ELISA binding against gp120 A244, gp120 MN, and p24 were positive in 98.6\%, 98.6\%, and 52.1\% of vaccinees at 12 months, respectively. The most striking parallel to declining immunogenicity over time was a 10 -fold drop in binding antibody to gp120 B and AE over the 6 months from the last vaccination.

\section{THE WAY FORWARD FROM RV144}

Identifying correlates of protection would revolutionize HIV-1 vaccine development. To this end, more than 30 investigators are collaborating to intensely characterize immune factors associated with vaccine efficacy (Kim et al. 2010). Studies include measures of Nab, ADCC, blocking of monoclonal antibody binding, immunoglobulin glycosylation and binding kinetics, phagocytosis, transcriptional profiling, immune phenotyping, and antigen specific cellular immune responses, cellular immunogenicity, host genetics testing, and other approaches to attempt to identify potential immune correlates or mechanisms of protection (Koup et al. 2010). Discovery of a correlate of protection from RV144 would provide a rational basis for further improvement of this regimen and newer vaccine approaches. In the absence of such a discovery, HIV vaccine development will have to build on RV144 in a more empirical fashion. This goal can be approached in two parallel, mutually supportive clinical development pathways (Fig. 1).

\section{Product Development Pathway}

This pathway takes the most direct extension from RV144, minimizes variable changes, and seeks the shortest pathway to licensure of a public health tool including the use of vaccines tailored for regional distribution of HIV subtypes in populations at highest risk for HIV infection. Because vaccine efficacy in RV144 appeared to wane from $60 \%$ at 12 months to $31 \%$ at 3.5 years, schedules incorporating booster doses will be evaluated in immunogenicity studies as a means to incrementally improve and sustain a vaccine efficacy $>50 \%$ at 24 months. Efficacy studies are being discussed in populations at high risk of HIV infection including heterosex- 


\section{South Africa Phllb}

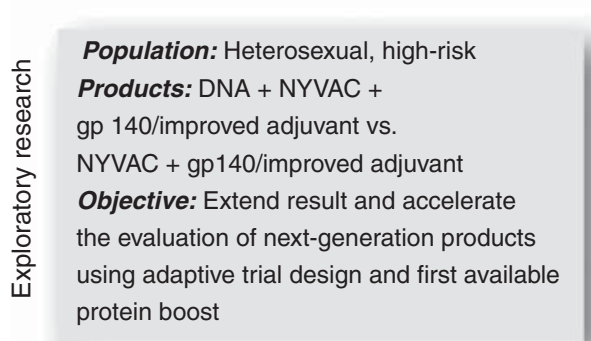

Thailand Phllb

RV 144 follow-up (Thailand)

\section{Studies:}

RV 144 immune correlates studies RV 305 protein boosting study

RV 306 expanded immunogenicity study

Objective: Determine correlate of protection for use in future trials; optimize the regimen

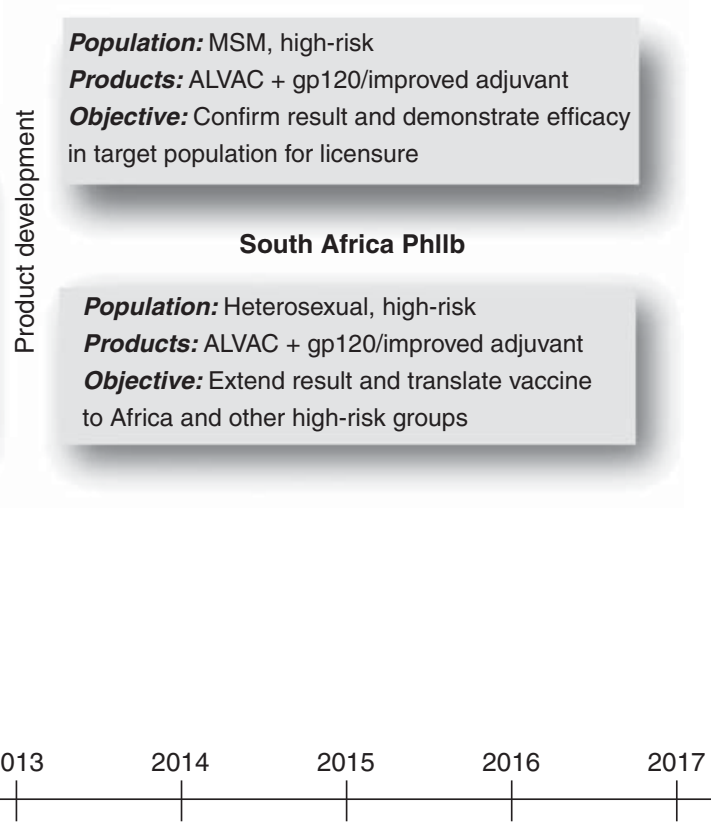

Figure 1. Global clinical AIDS vaccine development. Depicted are three distinct, but interrelated, spheres of activity placed along a timeline. RV144 follow-up is ongoing, and seeks to identify a correlate of immune protection by interrogating RV144 samples or samples generated by follow-up studies. Exploratory research activities will include adaptive design clinical trials, which aim to rapidly identify next generation products that should proceed to efficacy testing. Product development activities seek to extend the RV144 proof of concept by studying pox-protein prime-boost strategies in high-risk populations from Africa and Thailand with different routes of exposure in pursuit of licensure to realize rapid public health benefit.

uals in southern Africa and MSM in Thailand that could begin in 2014. These studies would build on RV144 by keeping vaccine constituents and schedule constant. Given that RV144 was conducted in a population at risk for primarily CRF01_AE infection, this variable would also be held constant in subsequent studies in Thailand. However, both the ALVAC inserts and the recombinant gp 120 protein to be tested in southern Africa would need to be substituted with subtype $\mathrm{C}$ strains that match the prevalent regional circulating HIV variants. Any change in vaccine, population, or subtype will impact comparability of the studies. Finally, the gp 120 recombinant protein boost for subsequent Thai and southern Africa studies has yet to be determined. This discussion is theoretically more straightforward for Thailand as AIDSVAX 
R.J. O'Connell et al.

$\mathrm{B} / \mathrm{E}$ is the established precedent but is less intuitive for studies elsewhere.

\section{Exploratory Research Pathway: Pox-Protein and Beyond}

Parallel exploration of novel pox vectors and gp120 proteins/adjuvants to improve protective efficacy is warranted through iterative clinical research. Poxvirus vectors, such as NYVAC, merit consideration for research track exploration as they appear to generate greater cellular and humoral immune responses than ALVAC. Although the relevance of those evoked immune responses to protective efficacy is unknown, products that evoke qualitative and quantitative differences in immunogenicity compared to RV144 should be evaluated. The rgp120 used in RV144 was formulated with alum, a relatively weak adjuvant. Studies using more potent adjuvants such as MF59, are warranted as well as rgp120s that generate novel immunogenicity profiles in phase I clinical studies. The use of accelerated clinical study designs that efficiently eliminate poorly performing vaccine candidates should be part of this exploratory research pathway (Koup et al. 2010; Corey et al. 2011).

RV144 and the subsequent immunogenicity and efficacy studies that are being currently discussed are limited by the need the need to match HIV subtypes to specific regional epidemics. Increasing the valency of HIV vaccine candidates to capture a broader range of global HIV subtype diversity would provide the possibility of a globally effective preventive vaccine. Such an advance could enable a concerted HIV elimination strategy similar to the smallpox eradication campaign (Breman and Arita 1980). These factors have prompted development of strategies aimed at generating responses broad enough to afford vaccine recipients universal protection. One promising approach involves the use of polyvalent "mosaic" inserts which cover the range of HIV T-cell epitopes across HIV subtypes (Fischer et al. 2007; Abdulhaqq and Weiner 2008; Barouch et al. 2010). Replication-incompetent Ad26 vectored mosaic HIV-1 Gag, Pol, and Env antigens augmented breadth and depth of cellular immune responses in rhesus monkeys (Barouch et al. 2010), and both Ad26 and Ad35 vectored HIV-1 vaccine candidates, the former in combination with MVA mosaics are moving forward into phase I human clinical trials.

\section{REFERENCES}

* Reference is also in this collection.

Abdulhaqq SA, Weiner DB. 2008. DNAvaccines: Developing new strategies to enhance immune responses. Immunol Res 42: 219-232.

Abrahams MR, Anderson JA, Giorgi EE, Seoighe C, Mlisana K, Ping LH, Athreya GS, Treurnicht FK, Keele BF, Wood N, et al. 2009. Quantitating the multiplicity of infection with human immunodeficiency virus type 1 subtype $\mathrm{C}$ reveals a non-Poisson distribution of transmitted variants. J Virol 83: 3556-3567.

Allen TM, Vogel TU, Fuller DH, Mothé BR, Steffen S, Boyson JE, Shipley T, Fuller J, Hanke T, Sette A, et al. 2000. Induction of AIDS virus-specific CTL activity in fresh, unstimulated peripheral blood lymphocytes from rhesus macaques vaccinated with a DNA prime/modified vaccinia virus Ankara boost regimen. J Immunol 164: 4968-4978.

Almeida JR, Price DA, Papagno L, Arkoub ZA, Sauce D, Bornstein E, Asher TE, Samri A, Schnuriger A, Theodorou I, et al. 2007. Superior control of HIV-1 replication by $\mathrm{CD}^{+} \mathrm{T}$ cells is reflected by their avidity, polyfunctionality, and clonal turnover. J Exp Med 204: 2473-2485.

Asmuth DM, Brown EL, DiNubile MJ, Sun X, del Rio C, Harro C, Keefer MC, Kublin JG, Dubey SA, Kierstead LS, et al. 2010. Comparative cell-mediated immunogenicity of DNA/DNA, DNA/adenovirus type 5 (Ad5), or Ad5/Ad5 HIV-1 clade B gag vaccine prime-boost regimens. J Infect Dis 201: 132-141.

Baba TW, Jeong YS, Pennick D, Bronson R, Greene MF, Ruprecht RM. 1995. Pathogenicity of live, attenuated SIV after mucosal infection of neonatal macaques. Science 267: $1820-1825$.

Baba TW, Liska V, Hofmann-Lehmann R, Vlasak J, Xu W, Ayehunie S, Cavacini LA, Posner MR, Katinger H, Stiegler G, et al. 2000. Human neutralizing monoclonal antibodies of the IgG1 subtype protect against mucosal simian-human immunodeficiency virus infection. Nat Med 6: 200-206.

Baden LR, Dolin R, O’Brien KL, Abbink P, La Porte A, Seaman MS, Choi E, Tucker R, Weithens M, Pau MG, et al. 2009. First-in-human Phase 1 safety and immunogenicity of an adenovirus serotype $26 \mathrm{HIV}-1$ vaccine vector. AIDS Vaccine 2009. Paris, France.

Barouch DH. 2008. Challenges in the development of an HIV-1 vaccine. Nature 455: 613-619.

Barouch DH. 2010. Novel adenovirus vector-based vaccines for HIV-1. Curr Opin HIVAIDS 5: 386-390.

Barouch DH, O’Brien KL, Simmons NL, King SL, Abbink P, Maxfield LF, Sun YH, La Porte A, Riggs AM, Lynch DM, et al. 2010. Mosaic HIV-1 vaccines expand the breadth 
and depth of cellular immune responses in rhesus monkeys. Nat Med 16: 319-323.

Baxby D, Paoletti E. 1992. Potential use of non-replicating vectors as recombinant vaccines. Vaccine 10: 8-9.

Belshe RB, Graham BS, Keefer MC, Gorse GJ, Wright P, Dolin R, Matthews T, Weinhold K, Bolognesi DP, Sposto R, et al. 1994. Neutralizing antibodies to HIV-1 in seronegative volunteers immunized with recombinant gp120 from the MN strain of HIV-1. NIAID AIDS Vaccine Clinical Trials Network. JAMA 272: 475-480.

Belshe RB, Gorse GJ, Mulligan MJ, Evans TG, Keefer MC, Excler JL, Duliege AM, Tartaglia J, Cox WI, McNamara J, et al. 1998. Induction of immune responses to HIV-1 by canarypox virus (ALVAC) HIV-1 and gp120 SF-2 recombinant vaccines in uninfected volunteers. NIAID AIDS Vaccine Evaluation Group. AIDS 12: 2407-2415.

Belshe RB, Stevens C, Gorse GJ, Buchbinder S, Weinhold K, Sheppard H, Stablein D, Self S, McNamara J, Frey S, et al. 2001. Safety and immunogenicity of a canarypoxvectored human immunodeficiency virus Type 1 vaccine with or without gp120: A phase 2 study in higher- and lower-risk volunteers. J Infect Dis 183: 1343-1352.

Benlahrech A, Harris J, Meiser A, Papagatsias T, Hornig J, Hayes P, Lieber A, Athanasopoulos T, Bachy V, Csomor E, et al. 2009. Adenovirus vector vaccination induces expansion of memory CD4 T cells with a mucosal homing phenotype that are readily susceptible to HIV-1. Proc Natl Acad Sci 106: 19940-19945.

Betts MR, Nason MC, West SM, De Rosa SC, Migueles SA, Abraham J, Lederman MM, Benito JM, Goepfert PA, Connors M, et al. 2006. HIV nonprogressors preferentially maintain highly functional HIV-specific $\mathrm{CD} 8^{+} \mathrm{T}$ cells. Blood 107: 4781-4789.

Bhattacharya T, Daniels M, Heckerman D, Foley B, Frahm N, Kadie C, Carlson J, Yusim K, McMahon B, Gaschen B, et al. 2007. Founder effects in the assessment of HIV polymorphisms and HLA allele associations. Science 315: $1583-1586$.

Blanchard TJ, Alcami A, Andrea P, Smith GL. 1998. Modified vaccinia virus Ankara undergoes limited replication in human cells and lacks several immunomodulatory proteins: Implications for use as a human vaccine. $J$ Gen Virol 79: 1159-1167.

Breman JG, Arita I. 1980. The confirmation and maintenance of smallpox eradication. $N$ Engl J Med 303: $1263-1273$.

Brumme ZL, Brumme CJ, Heckerman D, Korber BT, Daniels M, Carlson J, Kadie C, Bhattacharya T, Chui C, Szinger J, et al. 2007. Evidence of differential HLA class I-mediated viral evolution in functional and accessory/ regulatory genes of HIV-1. PLoS Pathog 3: e94.

Buchbinder S, Duerr A. 2009. Clinical outcomes from the Step study. AIDS Vaccine 2009. Paris, France.

Buchbinder SP, Mehrotra DV, Duerr A, Fitzgerald DW, Mogg R, Li D, Gilbert PB, Lama JR, Marmor M, Del Rio C, et al. 2008. Efficacy assessment of a cell-mediated immunity HIV-1 vaccine (the Step Study): A doubleblind, randomised, placebo-controlled, test-of-concept trial. Lancet 372: 1881-1893.

Burke DS. 1993. Vaccine therapy for HIV: A historical review of the treatment of infectious diseases by active specific immunization with microbe-derived antigens. Vaccine 11: $883-891$.

Carrington M, O'Brien SJ. 2003. The influence of HLA genotype on AIDS. Annu Rev Med 54: 535-551.

Carrington M, Nelson GW, Martin MP, Kissner T, Vlahov D, Goedert JJ, Kaslow R, Buchbinder S, Hoots K, O’Brien SJ. 1999. HLA and HIV-1: Heterozygote advantage and $\mathrm{B}^{*} 35-\mathrm{Cw}^{*} 04$ disadvantage. Science 283: 1748-1752.

Carroll MW, Moss B. 1997. Poxviruses as expression vectors. Curr Opin Biotechnol 8: 573-577.

Casimiro DR, Chen L, Fu TM, Evans RK, Caulfield MJ, Davies ME, Tang A, Chen M, Huang L, Harris V, et al. 2003. Comparative immunogenicity in rhesus monkeys of DNA plasmid, recombinant vaccinia virus, and replication-defective adenovirus vectors expressing a human immunodeficiency virus type 1 gag gene. J Virol 77: 6305-6313.

Casimiro DR, Wang F, Schleif WA, Liang X, Zhang ZQ, Tobery TW, Davies ME, McDermott AB, O'Connor DH, Fridman A, et al. 2005. Attenuation of simian immunodeficiency virus SIVmac239 infection by prophylactic immunization with dna and recombinant adenoviral vaccine vectors expressing Gag. J Virol 79: 15547-15555.

Catanzaro AT, Koup RA, Roederer M, Bailer RT, Enama ME, Moodie Z, Gu L, Martin JE, Novik L, Chakrabarti BK, et al. 2006. Phase 1 safety and immunogenicity evaluation of a multiclade HIV-1 candidate vaccine delivered by a replication-defective recombinant adenovirus vector. J Infect Dis 194: 1638-1649.

CDC 1999. Ten great public health achievements-United States, 1900-1999. MMWR Morb Mortal Wkly Rep 48: 241-243.

Catanzaro AT, Roederer M, Koup RA, Bailer RT, Enama ME, Nason MC, Martin JE, Rucker S, Andrews CA, Gomez PL, et al. 2007. Phase I clinical evaluation of a six-plasmid multiclade HIV-1 DNA candidate vaccine. Vaccine 25: 4085-4092.

Cebere I, Dorrell L, McShane H, Simmons A, McCormack S, Schmidt C, Smith C, Brooks M, Roberts JE, Darwin SC, et al. 2006. Phase I clinical trial safety of DNA- and modified virus Ankara-vectored human immunodeficiency virus type 1 (HIV-1) vaccines administered alone and in a prime-boost regime to healthy HIV-1-uninfected volunteers. Vaccine 24: 417-425.

Chun TW, Carruth L, Finzi D, Shen X, DiGiuseppe JA, Taylor H, Hermankova M, Chadwick K, Margolick J, Quinn TC, et al. 1997. Quantification of latent tissue reservoirs and total body viral load in HIV-1 infection. Nature 387: $183-188$.

Chun TW, Engel D, Berrey MM, Shea T, Corey L, Fauci AS. 1998. Early establishment of a pool of latently infected, resting $\mathrm{CD} 4^{+} \mathrm{T}$ cells during primary HIV-1 infection. Proc Natl Acad Sci 95: 8869-8873.

Clements-Mann ML, Weinhold K, Matthews TJ, Graham BS, Gorse GJ, Keefer MC, McElrath MJ, Hsieh RH, Mestecky J, Zolla-Pazner S, et al. 1998. Immune responses to human immunodeficiency virus (HIV) type 1 induced by canarypox expressing HIV-1MN gp120, HIV-1SF2 recombinant gp120, or both vaccines in seronegative adults. NIAID AIDS Vaccine Evaluation Group. J Infect Dis 177: $1230-1246$. 
R.J. O'Connell et al.

Cocchi F, DeVico AL, Garzino-Demo A, Arya SK, Gallo RC, Lusso P. 1995. Identification of RANTES, MIP- $1 \alpha$, and MIP-1 $\beta$ as the major HIV-suppressive factors produced by CD8 ${ }^{+}$T cells. Science 270: $1811-1815$.

Cohen J. 1997. Weakened SIV vaccine still kills. Science 278: 24-25.

Cooney EL, McElrath MJ, Corey L, Hu SL, Collier AC, Arditti D, Hoffman M, Coombs RW, Smith GE, Greenberg PD. 1993. Enhanced immunity to human immunodeficiency virus (HIV) envelope elicited by a combined vaccine regimen consisting of priming with a vaccinia recombinant expressing HIV envelope and boosting with gp160 protein. Proc Natl Acad Sci 90: 1882-1886.

Corey L, Nabel GJ, Dieffenbach C, Gilbert P, Haynes BF, Johnston M, Kublin J, Lane HC, Pantaleo G, Picker LJ, et al. 2011. HIV-1 vaccines and adaptive trial designs. Sci Transl Med 3: 79ps13.

Currier J, de Souza M. 2009. Characterization of cellmediated immune responses generated by a recombinant modified vaccinia Ankara (rMVA)-HIV-1 in a Phase I vaccine Trial. AIDS Vaccine 2009. Paris, France.

D’Souza MP, Frahm N. 2010. Adenovirus 5 serotype vectorspecific immunity and HIV-1 infection: A tale of T cells and antibodies. AIDS 24: 803-809.

D'Souza MP, Harden VA. 1996. Chemokines and HIV-1 second receptors. Confluence of two fields generates optimism in AIDS research. Nat Med 2: 1293-1300.

Daniel MD, Kirchhoff F, Czajak SC, Sehgal PK, Desrosiers RC. 1992. Protective effects of a live attenuated SIV vaccine with a deletion in the nef gene. Science 258: 1938-1941.

de Bruyn G, Rossini AJ, Chiu YL, Holman D, Elizaga ML Frey SE, Burke D, Evans TG, Corey L, Keefer MC. 2004. Safety profile of recombinant canarypox HIV vaccines. Vaccine 22: 704-713.

Deprez B, Sauzet JP, Boutillon C, Martinon F, Tartar A, Sergheraert C, Guillet JG, Gomard E, Gras-Masse H. 1996. Comparative efficiency of simple lipopeptide constructs for in vivo induction of virus-specific CTL. Vaccine 14: 375-382.

Deres K, Schild H, Wiesmuller KH, Jung G, Rammensee HG. 1989. In vivo priming of virus-specific cytotoxic T lymphocytes with synthetic lipopeptide vaccine. Nature 342: $561-564$.

Dorrell L, Williams P, Suttill A, Brown D, Roberts J, Conlon C, Hanke T, McMichael A. 2007. Safety and tolerability of recombinant modified vaccinia virus Ankara expressing an HIV-1 gag/multiepitope immunogen (MVA.HIVA) in HIV-1-infected persons receiving combination antiretroviral therapy. Vaccine 25: 3277-3283.

Douek DC, Kwong PD, Nabel GJ, et al. 2006. The rational design of an AIDS vaccine. Cell 124: 677-681.

Duerr A, Huang Y, Moodie Z, Lawrence D, Robertson M, Buchbinder S. 2010. Analyais of the relative risk of HIV acquisition among Step study participants with extended follow-up. AIDS Res Human Retroviruses 26: A-1-A-184. Oral Abstract OA03.05.

Evans TG, Keefer MC, Weinhold KJ, Wolff M, Montefiori D, Gorse GJ, Graham BS, McElrath MJ, Clements-Mann ML, Mulligan MJ, et al. 1999. A canarypox vaccine expressing multiple human immunodeficiency virus type 1 genes given alone or with rgp120 elicits broad and durable $\mathrm{CD}^{+}$cytotoxic T lymphocyte responses in seronegative volunteers. J Infect Dis 180: 290-298.

Excler JL, Plotkin S. 1997. The prime-boost concept applied to HIV preventive vaccines. AIDS 11: S127-S137.

Fauci AS, Johnston MI, Dieffenbach CW, Burton DR, Hammer SM, Hoxie JA, Martin M, Overbaugh J, Watkins DI, Mahmoud A, et al. 2008. HIV vaccine research: The way forward. Science 321: 530-532.

Fellay J, Shianna KV, Ge D, Colombo S, Ledergerber B, Weale M, Zhang K, Gumbs C, Castagna A, Cossarizza A, et al. 2007. A whole-genome association study of major determinants for host control of HIV-1. Science 317: 944-947.

Fischer W, Perkins S, Theiler J, Bhattacharya T, Yusim K, Funkhouser R, Kuiken C, Haynes B, Letvin NL, Walker $\mathrm{BD}$, et al. 2007. Polyvalent vaccines for optimal coverage of potential T-cell epitopes in global HIV-1 variants. Nat Med 13: 100-106.

Flynn NM, Forthal DN, Harro CD, Judson FN, Mayer KH, Para MF. 2005. Placebo-controlled phase 3 trial of a recombinant glycoprotein 120 vaccine to prevent HIV-1 infection. J Infect Dis 191: 654-665.

Forthal DN, Gilbert PB, Landucci G, Phan T. 2007. Recombinant gp120 vaccine-induced antibodies inhibit clinical strains of HIV-1 in the presence of Fc receptor-bearing effector cells and correlate inversely with HIV infection rate. J Immunol 178: 6596-6603.

Fouts TR, Binley JM, Trkola A, Robinson JE, Moore JP. 1997. Neutralization of the human immunodeficiency virus type 1 primary isolate JR-FL by human monoclonal antibodies correlates with antibody binding to the oligomeric form of the envelope glycoprotein complex. J Virol 71: 2779-2785.

Franchini G, Gurunathan S, Baglyos L, Plotkin S, Tartaglia J. 2004. Poxvirus-based vaccine candidates for HIV: Two decades of experience with special emphasis on canarypox vectors. Expert Rev Vaccines 3: S75-88.

Frey G, Peng H, Rits-Volloch S, Morelli M, Cheng Y, Chen B. 2008. A fusion-intermediate state of HIV-1 gp41 targeted by broadly neutralizing antibodies. Proc Natl Acad Sci 105: $3739-3744$

Gao X, Nelson GW, Karacki P, Martin MP, Phair J, Kaslow R, Goedert JJ, Buchbinder S, Hoots K, Vlahov D, et al. 2001. Effect of a single amino acid change in MHC class I molecules on the rate of progression to AIDS. $N$ Engl J Med 344: $1668-1675$.

Gaschen B, Taylor J, Yusim K, Foley B, Gao F, Lang D, Novitsky V, Haynes B, Hahn BH, Bhattacharya T, et al. 2002. Diversity considerations in HIV-1 vaccine selection. Science 296: 2354-2360.

Gilbert PB, Chiu YL, Allen M, Lawrence DN, Chapdu C, Israel H, Holman D, Keefer MC, Wolff M, Frey SE, et al. 2003. Long-term safety analysis of preventive HIV-1 vaccines evaluated in AIDS vaccine evaluation group NIAID-sponsored Phase I and II clinical trials. Vaccine 21-22: 2933-2947.

Gilbert PB, Peterson ML, Follmann D, Hudgens MG, Francis DP, Gurwith M, Heyward WL, Jobes DV, Popovic V, Self SG, et al. 2005. Correlation between immunologic responses to a recombinant glycoprotein 120 vaccine and incidence of HIV-1 infection in a phase 3 HIV-1 preventive vaccine trial. J Infect Dis 191: 666-677. 
Gilbert P, Wang M, Wrin T, Petropoulos C, Gurwith M, Sinangil F, D'Souza P, Rodriguez-Chavez IR, DeCamp A, Giganti M, et al. 2010. Magnitude and breadth of a nonprotective neutralizing antibody response in an efficacy trial of a candidate HIV-1 gp120 vaccine. J Infect Dis 202: 595-605.

Goonetilleke N, Moore S, Dally L, Winstone N, Cebere I, Mahmoud A, Pinheiro S, Gillespie G, Brown D, Loach $\mathrm{V}$, et al. 2006. Induction of multifunctional human immunodeficiency virus type 1 (HIV-1)-specific T cells capable of proliferation in healthy subjects by using a prime-boost regimen of DNA- and modified vaccinia virus Ankara-vectored vaccines expressing HIV-1 Gag coupled to CD8 ${ }^{+}$T-cell epitopes. J Virol 80: 4717-4728.

Goonetilleke N, Liu MK, Salazar-Gonzalez JF, Ferrari G, Giorgi E, Ganusov VV, Keele BF, Learn GH, Turnbull EL, Salazar MG, et al. 2009. The first T cell response to transmitted/founder virus contributes to the control of acute viremia in HIV-1 infection. J Exp Med 206: $1253-1272$.

Goulder PJ, Brander C, Tang Y, Tremblay C, Colbert RA, Addo MM, Rosenberg ES, Nguyen T, Allen R, Trocha A, et al. 2001. Evolution and transmission of stable CTL escape mutations in HIV infection. Nature 412: 334-338.

Goulder PJ, Watkins DI. 2004. HIV and SIV CTL escape: Implications for vaccine design. Nat Rev Immunol 4: 630-640.

Graham BS, McElrath MJ, Connor RI, Schwartz DH, Gorse GJ, Keefer MC, Mulligan MJ, Matthews TJ, Wolinsky SM, Montefiori DC, et al. 1998. Analysis of intercurrent human immunodeficiency virus type 1 infections in phase I and II trials of candidate AIDS vaccines. AIDS vaccine evaluation group, and the correlates of HIV immune protection group. J Infect Dis 177: 310-319.

Graham BS, Koup RA, Roederer M, Bailer RT, Enama ME, Moodie Z, Martin JE, McCluskey MM, Chakrabarti BK, Lamoreaux L, et al. 2006. Phase 1 safety and immunogenicity evaluation of a multiclade HIV-1 DNA candidate vaccine. J Infect Dis 194: 1650-1660.

Gudmundsdotter L, Nilsson C, Brave A, Hejdeman B, Earl P, Moss B, Robb M, Cox J, Michael N, Marovich M, et al. 2009. Recombinant Modified Vaccinia Ankara (MVA) effectively boosts DNA-primed HIV-specific immune responses in humans despite pre-existing vaccinia immunity. Vaccine 27: 4468-4474.

Guimarães-Walker A, Mackie N, McCormack S, Hanke T, Schmidt C, Gilmour J, Barin B, McMichael A, Weber J, Legg K, et al. 2008. Lessons from IAVI-006, a phase I clinical trial to evaluate the safety and immunogenicity of the pTHr.HIVA DNA and MVA.HIVA vaccines in a primeboost strategy to induce HIV-1 specific T-cell responses in healthy volunteers. Vaccine 26: 6671-6677.

Hanke T, Samuel RV, Blanchard TJ, Neumann VC, Allen TM, Boyson JE, Sharpe SA, Cook N, Smith GL, Watkins DI, et al. 1999. Effective induction of simian immunodeficiency virus-specific cytotoxic $\mathrm{T}$ lymphocytes in macaques by using a multiepitope gene and DNA primemodified vaccinia virus Ankara boost vaccination regimen. J Virol 73: 7524-7532.

Hanke T, Goonetilleke N, McMichael AJ, Dorrell L. 2007. Clinical experience with plasmid DNA- and modified vaccinia virus Ankara-vectored human immunodeficiency virus type 1 clade A vaccine focusing on T-cell induction. J Gen Virol 88: 1-12.

Harari A, Bart PA, Stohr W, Tapia G, Garcia M, MedjitnaRais E, Burnet S, Cellerai C, Erlwein O, Barber T, et al. 2008. An HIV-1 clade C DNA prime, NYVAC boost vaccine regimen induces reliable, polyfunctional, and longlasting T cell responses. J Exp Med 205: 63-77.

Harro CD, Judson FN, Gorse GJ, Mayer KH, Kostman JR, Brown SJ, Koblin B, Marmor M, Bartholow BN, Popovic $\mathrm{V}$, et al. 2004. Recruitment and baseline epidemiologic profile of participants in the first phase 3 HIV vaccine efficacy trial. J Acquir Immune Defic Syndr 37: 1385 1392.

Harro CD, Robertson MN, Lally MA, O'Neill LD, Edupuganti S, Goepfert PA, Mulligan MJ, Priddy FH, Dubey SA, Kierstead LS, et al. 2009. Safety and immunogenicity of adenovirus-vectored near-consensus HIV type 1 clade $\mathrm{B}$ gag vaccines in healthy adults. AIDS Res Hum Retroviruses 25: 103-114.

Haynes BF, Fleming J, St Clair EW, Katinger H, Stiegler G, Kunert R, Robinson J, Scearce RM, Plonk K, Staats HF, et al. 2005. Cardiolipin polyspecific autoreactivity in two broadly neutralizing HIV-1 antibodies. Science 308: 1906-1908.

Hessell AJ, Rakasz EG, Tehrani DM, Huber M, Weisgrau KL, Landucci G, Forthal N, Koff WC, Poignard P, Watkins DI, et al. 2010. Broadly neutralizing monoclonal antibodies 2F5 and 4E10 directed against the human immunodeficiency virus type $1 \mathrm{gp} 41$ membrane-proximal external region protect against mucosal challenge by simian-human immunodeficiency virus SHIVBa-L. J Virol 84: 1302-1313.

IAVI. 2010. Database of AIDS Vaccine Candidates in Clinical Trials. Retrieved 27 October, 2010, from http://www. iavireport.org/trials-db/Pages/default.aspx.

Jaoko W, Nakwagala FN, Anzala O, Manyonyi GO, Birungi J, Nanvubya A, Bashir F, Bhatt K, Ogutu H, Wakasiaka S, et al. 2008. Safety and immunogenicity of recombinant low-dosage HIV-1 Avaccine candidates vectored by plasmid pTHr DNA or modified vaccinia virus Ankara (MVA) in humans in East Africa. Vaccine 26: 2788-2795.

Joag SV, Liu ZQ, Stephens EB, Smith MS, Kumar A, Li Z, Wang C, Sheffer D, Jia F, Foresman L, et al. 1998. Oral immunization of macaques with attenuated vaccine virus induces protection against vaginally transmitted AIDS. J Virol 72: 9069-9078.

Johnson WE, Desrosiers RC. 2002. Viral persistence: HIV's strategies of immune system evasion. Annu Rev Med 53: 499-518.

Kannanganat S, Kapogiannis BG, Ibegbu C, Chennareddi L, Goepfert P, Robinson HL, Lennox J, Amara R. 2007. Human immunodeficiency virus type 1 controllers but not noncontrollers maintain CD4 T cells coexpressing three cytokines. J Virol 81: 12071-12076.

Karnasuta C, Paris RM, Cox JH, Nitayaphan S, Pitisuttithum P, Thongcharoen P, Brown AE, Gurunathan S, Tartaglia J, Heyward WL, et al. 2005. Antibody-dependent cell-mediated cytotoxic responses in participants enrolled in a phase I/II ALVAC-HIV/AIDSVAX B/E prime-boost HIV-1 vaccine trial in Thailand. Vaccine 23: $2522-2529$. 


\section{R.J. O'Connell et al.}

Kaslow RA, Carrington M, Apple R, Park L, Munoz A, Saah AJ, Goedert JJ, Winkler C, O’Brien SJ, Rinaldo C, et al. 1996. Influence of combinations of human major histocompatibility complex genes on the course of HIV-1 infection. Nat Med 2: 405-411.

Keele BF, Giorgi EE, Salazar-Gonzalez JF, Decker JM, Pham KT, Salazar MG, Sun C, Grayson T, Wang S, Li H, et al. 2008. Identification and characterization of transmitted and early founder virus envelopes in primary HIV-1 infection. Proc Natl Acad Sci 105: 7552-7557.

Kelleher AD, Emery S, Cunningham P, Duncombe C, Carr A, Golding H, Forde S, Hudson J, Roggensack M, Forrest BD, et al. 1997. Safety and immunogenicity of UBI HIV-1MN octameric V3 peptide vaccine administered by subcutaneous injection. AIDS Res Hum Retroviruses 13: $29-32$

Kennedy JS, Co M, Green S, Longtine K, Longtine J, O’Neill MA, Adams JP, Rothman AL, Yu Q, Johnson-Leva R, et al. 2008. The safety and tolerability of an HIV-1 DNA primeprotein boost vaccine (DP6-001) in healthy adult volunteers. Vaccine 26: 4420-4424.

Kibuuka H, Kimutai R, Maboko L, Sawe F, Schunk MS, Kroidl A, Shaffer D, Eller LA, Kibaya R, Eller MA, et al. 2010. A phase $1 / 2$ study of a multiclade HIV-1 DNA plasmid prime and recombinant adenovirus serotype 5 boost vaccine in HIV-Uninfected East Africans (RV 172). $J$ Infect Dis 201: 600-607.

Kiepiela P, Leslie AJ, Honeyborne I, Ramduth D, Thobakgale C, Chetty S, Rathnavalu P, Moore C, Pfafferott KJ, Hilton L, et al. 2004. Dominant influence of HLA-B in mediating the potential co-evolution of HIV and HLA. Nature 432: $769-775$.

Kim JH, Rerks-Ngarm S, Excler JL, Michael NL. 2010. HIV vaccines: Lessons learned and the way forward. Curr Opin HIVAIDS 5: 428-434.

Korber BT, Letvin NL, Haynes BF. 2009. T-cell vaccine strategies for human immunodeficiency virus, the virus with a thousand faces. J Virol 83: 8300-8314.

Kostense S, Koudstaal W, Sprangers M, Weverling GJ, Penders G, Helmus N, Vogels R, Bakker M, Berkhout B, Havenga M, et al. 2004. Adenovirus types 5 and 35 seroprevalence in AIDS risk groups supports type 35 as a vaccine vector. AIDS 18: $1213-1216$.

Koup RA, Graham BS, Douek DC. 2010. The quest for a T cell-based immune correlate of protection against HIV: A story of trials and errors. Nat Rev Immunol 11: 65-70.

* Lackner AA, Lederman MM, Rodriguez B. 2011. HIV pathogenesis-The host. Cold Spring Harb Perspect Med doi: $10.1101 /$ cshperspect.a007005.

Letvin NL, Mascola JR, Sun Y, Gorgone DA, Buzby AP, Xu L, Yang ZY, Chakrabarti B, Rao SS, Schmitz JE, et al. 2006 Preserved $\mathrm{CD}^{+}{ }^{+}$central memory T cells and survival in vaccinated SIV-challenged monkeys. Science 312: 1530 1533.

Letvin NL, Rao SS, Montefiori DC, Seaman MS, Sun Y, Lim SY, Asmal M, Gelman RS, Shen L, Whitney JB, et al. 2011. Immune and genetic correlates of vaccine protection against mucosal infection by SIV in monkeys. Sci Transl Med 3: 81 ra36.

Lifson JD, Rossio JL, Piatak M Jr, Bess J Jr, Chertova E, Schneider DK, Coalter VJ, Poore B, Kiser RF, Imming RJ, et al. 2004. Evaluation of the safety, immunogenicity, and protective efficacy of whole inactivated simian immunodeficiency virus (SIV) vaccines with conformationally and functionally intact envelope glycoproteins. AIDS Res Hum Retroviruses 20: 772-787.

Limou S, Le Clerc S, Coulonges C, Carpentier W, Dina C, Delaneau O, Labib T, Taing L, Sladek R, Deveau C, et al. 2009. Genomewide association study of an AIDSnonprogression cohort emphasizes the role played by HLA genes (ANRS Genomewide Association Study 02). J Infect Dis 199: 419-426.

Liu J, O’Brien KL, Lynch DM, Simmons NL, La Porte A Riggs AM, Abbink P, Coffey RT, Grandpre LE, Seaman LS, et al. 2009. Immune control of an SIV challenge by a T-cell-based vaccine in rhesus monkeys. Nature 457: 87-91.

MacGregor RR, Boyer JD, Ugen KE, Lacy KE, Gluckman SJ, Bagarazzi ML, Chattergoon MA, Baine Y, Higgins TJ, Ciccarelli RB, et al. 1998. First human trial of a DNAbased vaccine for treatment of human immunodeficiency virus type 1 infection: Safety and host response. J Infect Dis 178: $92-100$.

MacGregor RR, Boyer JD, Ciccarelli RB, Ginsberg RS, Weiner DB. 2000. Safety and immune responses to a DNA-based human immunodeficiency virus (HIV) type I env/rev vaccine in HIV-infected recipients: Follow-up data. J Infect Dis 181: 406.

MacGregor RR, Ginsberg R, Ugen KE, Baine Y, Kang CU, Tu XM, Higgins T, Weiner DB, Boyer JD. 2002. T-cell responses induced in normal volunteers immunized with a DNA-based vaccine containing HIV-1 env and rev. AIDS 16: 2137-2143.

Mackewicz CE, Barker E, Levy JA. 1996. Role of $\beta$-chemokines in suppressing HIV replication. Science 274: 1393 1395.

Mariani R, Kirchhoff F, Greenough TC, Sullivan JL, Desrosiers RC, Skowronski J. 1996. High frequency of defective nef alleles in a long-term survivor with nonprogressive human immunodeficiency virus type 1 infection. J Virol 70: 7752-7764.

Markel H. 2004. Taking shots: The modern miracle of vaccines. Medscape Pediatrics 6. www.medscape.com/view article/481059.

Mascola JR, Montefiori DC. 2010. The role of antibodies in HIV vaccines. Annu Rev Immunol 28: 413-444.

Mascola JR, Stiegler G, VanCott TC, Katinger H, Carpenter CB, Hanson CE, Beary H, Hayes D, Frankel SS, Birx DL, et al. 2000. Protection of macaques against vaginal transmission of a pathogenic HIV-1/SIV chimeric virus by passive infusion of neutralizing antibodies. Nat Med 6: 207-210.

Masek-Hammerman K, Li H, Liu J, Abbink P, La Porte A, O’Brien KL, Whitney JB, Carville A, Mansfield KG, Barouch DH. 2010. Mucosal trafficking of vector-specific $\mathrm{CD}^{+} \mathrm{T}$ lymphocytes following vaccination of rhesus monkeys with adenovirus serotype 5. J Virol 84: 98109816.

McDermott AB, Mitchen J, Piaskowski S, De Souza I, Yant LJ, Stephany J, Furlott J, Watkins DI. 2004. Repeated lowdose mucosal simian immunodeficiency virus SIVmac239 challenge results in the same viral and immunological kinetics as high-dose challenge: A model for the 
evaluation of vaccine efficacy in nonhuman primates. $J$ Virol 78: 3140-3144.

McElrath MJ, De Rosa SC, Moodie Z, Dubey S, Kierstead L, Janes H, Defawe OD, Carter DK, Hural J, Akondy R, et al. 2008. HIV-1 vaccine-induced immunity in the test-of-concept Step Study: A case-cohort analysis. Lancet 372: 1894-1905.

McMichael AJ. 2006. HIV vaccines. Annu Rev Immunol 24: 227-255.

McMichael AJ, Borrow P, Tomaras GD, Goonetilleke N, Haynes BF. 2010. The immune response during acute HIV-1 infection: Clues for vaccine development. Nat Rev Immunol 10: 11-23.

Merial 2010. ProteqFlu Harlow, UK, Merial Animal Health, Ltd. 2010.

Michael NL. 2009. Primary and sub-group analyses of the Thai Phase III HIV Vaccine Trial. AIDS Vaccine. Paris, France.

Moore CB, John M, James IR, Christiansen FT, Witt CS, Mallal SA. 2002. Evidence of HIV-1 adaptation to HLA-restricted immune responses at a population level. Science 296: 1439-1443.

Moore PL, Ranchobe N, Lambson BE, Gray ES, Cave E, Abrahams MR, Bandawe G, Mlisana K, Abdool Karim SS, Williamson C, et al. 2009. Limited neutralizing antibody specificities drive neutralization escape in early HIV-1 subtype C infection. PLoS Pathog 5: e1000598.

Moss B. 1991. Vaccinia virus: A tool for research and vaccine development. Science 252: 1662-1667.

Moss B, Carroll MW, Wyatt LS, Bennink JR, Hirsch VM, Goldstein S, Elkins WR, Fuerst TR, Lifson JD, Piatak $\mathrm{M}$, et al. 1996. Host range restricted, non-replicating vaccinia virus vectors as vaccine candidates. Adv Exp Med Biol 397: 7-13.

Mwau M, Cebere I, Sutton J, Chikoti P, Winstone N, Wee EG, Beattie T, Chen YH, Dorrell L, McShane H, et al. 2004. A human immunodeficiency virus 1 (HIV-1) clade A vaccine in clinical trials: Stimulation of HIV-specific T-cell responses by DNA and recombinant modified vaccinia virus Ankara (MVA) vaccines in humans. J Gen Virol 85: 911-919.

Nitayaphan S, Pitisuttithum P, Karnasuta C, Eamsila C, de Souza M, Morgan P, Polonis V, Benenson M, VanCott T, Ratto-Kim S, et al. 2004. Safety and immunogenicity of an HIV subtype B and E prime-boost vaccine combination in HIV-negative Thai adults. J Infect Dis 190: 702-706.

Pantaleo G, Koup RA. 2004. Correlates of immune protection in HIV-1 infection: What we know, what we don't know, what we should know. Nat Med 10: 806-810.

Pantophlet R, Burton DR. 2006. GP120: Target for neutralizing HIV-1 antibodies. Anпu Rev Immunol 24: 739-769.

Paoletti E. 1996. Applications of pox virus vectors to vaccination: An update. Proc Natl Acad Sci 93: 11349-11353.

Paris RM, Kim JH, Robb ML, Michael NL. 2010. Primeboost immunization with poxvirus or adenovirus vectors as a strategy to develop a protective vaccine for HIV-1. Expert Rev Vaccines 9: 1055-1069.

Patel V, Valentin A, Kulkarni V, Rosati M, Bergamaschi C, Jalah R, Alicea C, Minang JT, Trivett MT, Ohlen C, et al. 2010. Long-lasting humoral and cellular immune responses and mucosal dissemination after intramuscular DNA immunization. Vaccine 28: 4827-4836.

Pelak K, Goldstein DB, Walley NM, Fellay J, Ge D, Shianna KV, Gumbs C, Gao X, Maia JM, Cronin KD, et al. 2010. Host determinants of HIV-1 control in African Americans. J Infect Dis 201: 1141-1149.

Pereyra F, Addo MM, Kaufmann DE, Liu Y, Miura T, Rathod A, Baker B, Trocha A, Rosenberg R, Mackey E, et al. 2008. Genetic and immunologic heterogeneity among persons who control HIV infection in the absence of therapy. $J$ Infect Dis 197: 563-571.

Pereyra F, Jia X, et al. 2010. The major genetic determinants of HIV-1 control affect HLA class I peptide presentation. Science 330: 1551-1557.

Peters BS, Jaoko W, Vardas E, Panayotakopoulos G, Fast P, Schmidt C, Gilmour J, Bogoshi M, Omosa-Manyonyi G, Dally L, et al. 2007. Studies of a prophylactic HIV-1 vaccine candidate based on modified vaccinia virus Ankara (MVA) with and without DNA priming: Effects of dosage and route on safety and immunogenicity. Vaccine 25: 2120-2127.

Pialoux G, Excler JL, Riviere Y, Gonzalez-Canali G, Feuillie V, Coulaud P, Gluckman JC, Matthews TJ, Meignier B, Kieny MP, et al. 1995. A prime-boost approach to HIV preventive vaccine using a recombinant canarypox virus expressing glycoprotein 160 (MN) followed by a recombinant glycoprotein 160 (MN/LAI). The AGIS Group, and l'Agence Nationale de Recherche sur le SIDA. AIDS Res Hum Retroviruses 11: 373-381.

Pitisuttithum P. 2008. HIV vaccine research in Thailand: Lessons learned. Expert Rev Vaccines 7: 311-317.

Pitisuttithum P, Nitayaphan S, Thongcharoen P, Khamboonruang C, Kim J, de Souza M, Chuenchitra T, Garner RP, Thapinta D, Polonis V, et al. 2003. Safety and immunogenicity of combinations of recombinant subtype $\mathrm{E}$ and B human immunodeficiency virus type 1 envelope glycoprotein 120 vaccines in healthy Thai adults. J Infect Dis 188: 219-227.

Pitisuttithum P, Berman PW, Phonrat B, Suntharasamai P, Raktham S, Srisuwanvilai LO, Hirunras K, Kitayaporn D, Kaewkangwal J, Migasena S, et al. 2004. Phase I/II study of a candidate vaccine designed against the B and E subtypes of HIV-1. J Acquir Immune Defic Syndr 37: 1160-1165.

Pitisuttithum P, Gilbert P, Gurwith M, Heyward W, Martin M, van Griensven F, Hu D, Tappero JW, Choopanya K. 2006. Randomized, double-blind, placebo-controlled efficacy trial of a bivalent recombinant glycoprotein 120 HIV-1 vaccine among injection drug users in Bangkok, Thailand. J Infect Dis 194: 1661-1671.

Plotkin SA. 2008. Vaccines: Correlates of vaccine-induced immunity. Clin Infect Dis 47: 401-409.

Poon B, Hsu JF, Gudeman V, Chen IS, Grovit-Ferbas K. 2005. Formaldehyde-treated, heat-inactivated virions with increased human immunodeficiency virus type 1 env can be used to induce high-titer neutralizing antibody responses. J Virol 79: 10210-10217.

Poropatich K, Sullivan DJ Jr. 2010. HIV-1 long-term nonprogressors: The viral, genetic and immunological basis for disease non-progression. J Gen Virol. 


\section{R.J. O'Connell et al.}

Potter SJ, Lacabaratz C, Lambotte O, Perez-Patrigeon S, Vingert B, Sinet M, Colle JH, Urrutia A, Scott-Algara E, Boufassa F, et al. 2007. Preserved central memory and activated effector memory $\mathrm{CD} 4^{+} \mathrm{T}$-cell subsets in human immunodeficiency virus controllers: An ANRS EP36 study. J Virol 81: 13904-13915.

Priddy FH, Brown D, Kublin J, Monahan K, Wright DP, Lalezari J, Santiago S, Marmor M, Lally M, Novak RM, et al. 2008. Safety and immunogenicity of a replication incompetent adenovirus type 5 HIV-1 clade B gag/pol/ nef vaccine in healthy adults. Clin Infect Dis 46: 1769-1781.

Ramanathan VD, Kumar M, Mahalingam J, Sathyamoorthy P, Narayanan PR, Solomon S, Panicali D, Chakrabarty S, Cox J, Sayeed E, et al. 2009. A Phase 1 study to evaluate the safety and immunogenicity of a recombinant HIV type 1 subtype $C$-modified vaccinia Ankara virus vaccine candidate in Indian volunteers. AIDS Res Hum Retroviruses 25: 1107-1116.

Ranasinghe C, Ramshaw IA. 2009. Genetic heterologous prime-boost vaccination strategies for improved systemic and mucosal immunity. Expert Rev Vaccines 8: 11711181.

Rerks-Ngarm S, Pitisuttithum P, Nitayaphan S, Kaewkungwal J, Chiu J, Paris R, Premsri N, Namwat C, de Souza M, Adams E, et al. 2009. Vaccination with ALVAC and AIDSVAX to prevent HIV-1 infection in Thailand. N Engl J Med 361: 2209-2220.

Richman DD, Wrin T, Little SJ, Petropoulos CJ. 2003. Rapid evolution of the neutralizing antibody response to HIV type 1 infection. Proc Natl Acad Sci 100: 4144-4149.

Robinson H, Goepfert P, Hay P, Team HP. 2008. GeoVax clade B DNA/MVA HIV/AIDS vaccine is well tolerated and immunogenic when administered to healthy seronegative adults. Conference on Retroviruses and Opportunistic Infections, Boston, MA

Rosati M, Valentin A, Jalah R, Patel V, von Gegerfelt A, Bergamaschi C, Alicea C, Weiss D, Treece J, Pal R, et al. 2008. Increased immune responses in rhesus macaques by DNA vaccination combined with electroporation. Vaccine 26: 5223-5229.

Roy MJ, Wu MS, Barr LJ, Fuller JT, Tussey LG, Speller S, Culp J, Burkholder JK, Swain WF, Dixon RM, et al. 2000. Induction of antigen-specific $\mathrm{CD} 8^{+} \mathrm{T}$ cells, $\mathrm{T}$ helper cells, and protective levels of antibody in humans by particlemediated administration of a hepatitis B virus DNA vaccine. Vaccine 19: 764-778.

Russell ND, Graham BS, Keefer MC, McElrath MJ, Self SG, Weinhold KJ, Montefiori DC, Ferrari G, Horton H, Tomaras GD, et al. 2007. Phase 2 study of an HIV-1 canarypox vaccine (vCP1452) alone and in combination with rgp120: Negative results fail to trigger a phase 3 correlates trial. J Acquir Immune Defic Syndr 44: 203-212.

Salazar-Gonzalez JF, Salazar MG, Keele BF, Learn GH, Giorgi EE, Li H, Decker JM, Wang S, Baalwa J, Kraus MH, et al. 2009. Genetic identity, biological phenotype, and evolutionary pathways of transmitted/founder viruses in acute and early HIV-1 infection. J Exp Med 206: 1273-1289.

Salmon-Céron D, Excler JL, Finkielsztejn L, Autran B, Gluckman JC, Sicard D, Matthews TJ, Meignier B, Valentin C, El Habib R, et al. 1999. Safety and immunogenicity of a live recombinant canarypox virus expressing HIV type 1 gp120 MN MN tm/gag/protease LAI (ALVAC-HIV, vCP205) followed by a p24E-V3 MN synthetic peptide (CLTB-36) administered in healthy volunteers at low risk for HIV infection. AGIS Group and L'Agence Nationale de Recherches sur Le Sida. AIDS Res Hum Retroviruses 15: 633-645.

Salmon-Céron D, Durier C, Desaint C, Cuzin L, Surenaud M, Hamouda NB, Lelièvre JD, Bonnet B, Pialoux G, PoizotMartin I, et al. 2010. Immunogenicity and safety of an HIV-1 lipopeptide vaccine in healthy adults: A phase 2 placebo-controlled ANRS trial. AIDS 24: 2211-2223.

Sandström E, Nilsson C, Hejdeman B, Bråve A, Bratt G, Robb M, Cox J, Vancott T, Marovich M, Stout R, et al. 2008. Broad immunogenicity of a multigene, multiclade HIV-1 DNA vaccine boosted with heterologous HIV-1 recombinant modified vaccinia virus Ankara. $J$ Infect Dis 198: 1482-1490.

Serwanga J, Shafer LA, Pimego E, Auma B, Watera C, Rowland S, Yirrell D, Pala P, Grosskurth H, Whitworth J, et al. 2009. Host HLA B*allele-associated multi-clade Gag T-cell recognition correlates with slow HIV-1 disease progression in antiretroviral therapy-naive Ugandans. PLoS One 4: e4188.

Shiver JW, Fu TM, Chen L, Casimiro DR, Davies ME, Evans RK, Zhang ZQ, Simon AJ, Trigona WL, Dubey SA, et al. 2002. Replication-incompetent adenoviral vaccine vector elicits effective anti-immunodeficiency-virus immunity. Nature 415: 331-335.

Simek MD, Rida W, Priddy FH, Pung P, Carrow E, Laufer DS, Lehrman JK, Boaz M, Tarragona-Fiol T, Miiro G, et al. 2009. Human immunodeficiency virus type 1 elite neutralizers: Individuals with broad and potent neutralizing activity identified by using a high-throughput neutralization assay together with an analytical selection algorithm. J Virol 83: 7337-7348.

Singh P, Kaur G, Sharma G, Mehra NK. 2008. Immunogenetic basis of HIV-1 infection, transmission and disease progression. Vaccine 26: 2966-2980.

Spearman P. 2006. Current progress in the development of HIV vaccines. Curr Pharm Des 12: 1147-1167.

Sun ZY, Oh KJ, Kim M, Yu J, Brusic V, Song L, Qiao Z, Wang JH, Wagner G, Reinherz EL. 2008. HIV-1 broadly neutralizing antibody extracts its epitope from a kinked gp41 ectodomain region on the viral membrane. Immunity 28: $52-63$.

Sutter G, Staib C. 2003. Vaccinia vectors as candidate vaccines: The development of modified vaccinia virus Ankara for antigen delivery. Curr Drug Targets Infect Disord 3: 263-271.

Tartaglia J, Cox WI, Taylor J, Perkus M, Riviere M, Meignier B, Paoletti E. 1992. Highly attenuated poxvirus vectors. AIDS Res Hum Retroviruses 8: 1445-1447.

Taylor J, Weinberg R, Languet B, Desmettre P, Paoletti E. 1988. Recombinant fowlpox virus inducing protective immunity in non-avian species. Vaccine 6: 497-503.

Thongcharoen P, Suriyanon V, Paris RM, Khamboonruang C, de Souza MS, Ratto-Kim S, Karnasuta C, Polonis VR, Baglyos L, Habib RE, et al. 2007. A phase $1 / 2$ comparative vaccine trial of the safety and immunogenicity of a CRF01_AE (subtype E) candidate vaccine: ALVAC-HIV (vCP1521) prime with oligomeric gp160 (92TH023/LAI- 
DID) or bivalent gp120 (CM235/SF2) boost. J Acquir Immune Defic Syndr 46: 48-55.

TIHC. 2010. The major genetic determinants of HIV-1 control affect HLA class I peptide presentation. Science doi: 101126/science1195271.

Tartaglia J, Cox WI, et al. 1992. Highly attenuated poxvirus vectors. AIDS Res Hum Retroviruses 8: 1445-1447.

Treurnicht FK, Seoighe C, Martin DP, Wood N, Abrahams MR, Rosa Dde A, Bredell H, Woodman Z, Hide W, Mlisana K, et al. 2010. Adaptive changes in HIV-1 subtype $\mathrm{C}$ proteins during early infection are driven by changes in HLA-associated immune pressure. Virology 396: $213-225$.

Vaccari M, Poonam P, Franchini G. 2010. Phase III HIV vaccine trial in Thailand: A step toward a protective vaccine for HIV. Expert Rev Vaccines 9: 997-1005.

Van Rompay KK, Abel K, Lawson JR, Singh RP, Schmidt KA, Evans T, Earl P, Harvey D, Franchini G, Tartaglia J, et al. 2005. Attenuated poxvirus-based simian immunodeficiency virus (SIV) vaccines given in infancy partially protect infant and juvenile macaques against repeated oral challenge with virulent SIV. J Acquir Immune Defic Syndr 38: 124-134.

VanCott TC, Mascola JR, Kaminski RW, Kalyanaraman V, Hallberg PL, Burnett PR, Ulrich JT, Rechtman DJ, Birx DL. 1997. Antibodies with specificity to native gp120 and neutralization activity against primary human immunodeficiency virus type 1 isolates elicited by immunization with oligomeric gp160. J Virol 71: 4319-4330.

Vasan S, Hurley A, Schlesinger SJ, Hannaman D, Gardiner DF, Dugin DP, Boente-Carrera M, Vittorino R, Caskey $\mathrm{M}$, Andersen J, et al. 2009. In vivo electroporation enhances the immunogenicity of ADVAX, a DNA-based HIV-1 vaccine candidate, in healthy volunteers. Retrovirology 6: $\mathrm{O} 31$.

Vasan S, Schlesinger SJ, Chen Z, Hurley A, Lombardo A, Than S, Adesanya P, Bunce C, Boaz M, Boyle R, et al. 2010a. Phase 1 safety and immunogenicity evaluation of ADMVA, a multigenic, modified vaccinia AnkaraHIV-1 B'/C candidate vaccine. PLoS One 5: e8816.

Vasan S, Schlesinger SJ, Huang Y, Hurley A, Lombardo A, Chen Z, Than S, Adesanya P, Bunce C, Boaz M, et al. 2010b. Phase 1 safety and immunogenicity evaluation of ADVAX, a multigenic, DNA-based clade C/B' HIV-1 candidate vaccine. PLoS One 5: e8617.
Walker BD, Korber BT. 2001. Immune control of HIV: The obstacles of HLA and viral diversity. Nat Immunol 2: $473-475$.

Wang R, Doolan DL, Le TP, Hedstrom RC, Coonan KM, Charoenvit Y, Jones TR, Hobart P, Margalith M, Ng J, et al. 1998. Induction of antigen-specific cytotoxic T lymphocytes in humans by a malaria DNA vaccine. Science 282: $476-480$.

Wang S, Kennedy JS, West K, Montefiori DC, Coley S, Lawrence J, Shen S, Green S, Rothman AL, Ennis FA, et al. 2008. Cross-subtype antibody and cellular immune responses induced by a polyvalent DNA prime-protein boost HIV-1 vaccine in healthy human volunteers. Vaccine 26: 3947-3957.

Watkins DI, Burton DR, Kallas EG, Moore JP, Koff WC. 2008. Nonhuman primate models and the failure of the Merck HIV-1 vaccine in humans. Nat Med 14: 617-621.

Wei X, Decker JM, Wang S, Hui H, Kappes JC, Wu X, Salazar-Gonzalez JF, Salazar MG, Kilby JM, Saag MS, et al. 2003. Antibody neutralization and escape by HIV-1. Nature 422: 307-312.

Whatmore AM, Cook N, Hall GA, Sharpe S, Rud EW, Cranage MP. 1995. Repair and evolution of nef in vivo modulates simian immunodeficiency virus virulence. J Virol 69: $5117-5123$.

Wilson NA, Reed J, Napoe GS, Piaskowski S, Szymanski A, Furlott J, Gonzalez EJ, Yant LJ, Maness NJ, May GE, et al. 2006. Vaccine-induced cellular immune responses reduce plasma viral concentrations after repeated lowdose challenge with pathogenic simian immunodeficiency virus SIVmac239. J Virol 80: 5875-5885.

Wilson NA, Keele BF, Reed JS, Piaskowski SM, MacNair CE, Bett AJ, Liang X, Wang F, Thoryk E, et al. 2009. Vaccine-induced cellular responses control simian immunodeficiency virus replication after heterologous challenge. J Virol 83: 6508-6521.

Wyand MS, Manson K, Montefiori DC, Lifson JD, Johnson RP, Desrosiers RC. 1999. Protection by live, attenuated simian immunodeficiency virus against heterologous challenge. J Virol 73: 8356-8363.

Zhou T, Georgiev I, Wu X, Yang ZY, Dai K, Finzi A, Kwon YD, Scheid JF, Shi W, Xu L, et al. 2010. Structural basis for broad and potent neutralization of HIV-1 by antibody VRC01. Science 329: 811-817. 


\section{$\&_{\mathrm{CSH}}^{\infty} \&$ Cold Spring Harbor

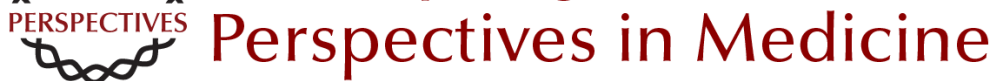

\section{Human Immunodeficiency Virus Vaccine Trials}

Robert J. O'Connell, Jerome H. Kim, Lawrence Corey and Nelson L. Michael

Cold Spring Harb Perspect Med 2012; doi: 10.1101/cshperspect.a007351

\section{Subject Collection HIV}

HIV Pathogenesis: Dynamics and Genetics of

Viral Populations and Infected Cells John Coffin and Ronald Swanstrom

Human Immunodeficiency Virus Vaccine Trials Robert J. O'Connell, Jerome H. Kim, Lawrence Corey, et al.

HIV Transmission George M. Shaw and Eric Hunter

Novel Cell and Gene Therapies for HIV James A. Hoxie and Carl H. June

\section{Behavioral and Biomedical Combination}

Strategies for HIV Prevention Linda-Gail Bekker, Chris Beyrer and Thomas C. Quinn

HIV-1 Assembly, Budding, and Maturation Wesley I. Sundquist and Hans-Georg Kräusslich

HIV-1 Assembly, Budding, and Maturation Wesley I. Sundquist and Hans-Georg Kräusslich

Lessons in Nonhuman Primate Models for AIDS Vaccine Research: From Minefields to Milestones Jeffrey D. Lifson and Nancy L. Haigwood
HIV-1 Pathogenesis: The Virus Ronald Swanstrom and John Coffin

The T-Cell Response to HIV Bruce Walker and Andrew McMichael

HIV-1 Reverse Transcription Wei-Shau Hu and Stephen H. Hughes

HIV Pathogenesis: The Host A.A. Lackner, Michael M. Lederman and Benigno Rodriguez

HIV: Cell Binding and Entry Craig B. Wilen, John C. Tilton and Robert W. Doms

Innate Immune Control of HIV Mary Carrington and Galit Alter

HIV DNA Integration Robert Craigie and Frederic D. Bushman

HIV-1-Related Central Nervous System Disease: Current Issues in Pathogenesis, Diagnosis, and Treatment Serena Spudich and Francisco González-Scarano

For additional articles in this collection, see http://perspectivesinmedicine.cshlp.org/cgi/collection/ 